Research Article

\title{
Impact of Large-Scale Climate Indices on Meteorological Drought of Coastal Ghana
}

\author{
Martin Addi $\mathbb{D}^{1}{ }^{1}$ Kofi Asare $\mathbb{D}^{1},{ }^{1}$ Samuel Kofi Fosuhene, ${ }^{1}$ Theophilus Ansah-Narh $\left(\mathbb{D},{ }^{2}\right.$ \\ Kenneth Aidoo, ${ }^{1}$ and Comfort Gyasiwaa Botchway ${ }^{1}$ \\ ${ }^{1}$ Remote Sensing and Climate Centre, Ghana Space Science and Technology Institute, GAEC, Accra, Ghana \\ ${ }^{2}$ Radio Astronomy and Astrophysics Centre, Ghana Space Science and Technology Institute, GAEC, Accra, Ghana \\ Correspondence should be addressed to Martin Addi; addimartin32@yahoo.com
}

Received 17 March 2020; Revised 24 December 2020; Accepted 10 January 2021; Published 3 February 2021

Academic Editor: Marina Baldi

Copyright (C) 2021 Martin Addi et al. This is an open access article distributed under the Creative Commons Attribution License, which permits unrestricted use, distribution, and reproduction in any medium, provided the original work is properly cited.

\begin{abstract}
The devastating effects of drought on agriculture, water resources, and other socioeconomic activities have severe consequences on food security and water resource management. Understanding the mechanism that drives drought and predicting its variability is important for enhancing early warning and disaster risk management. In this study, meteorological droughts over six coastal synoptic stations were investigated using three-month Standardized Precipitation Index (SPI). The dry seasons of NovemberDecember-January (NDJ), December-January-February (DJF), and January-February-March (JFM) were the focal seasons for the study. Trends of dry seasons SPIs were evaluated using seasonal Mann-Kendall test. The relationship between drought SPI and ocean-atmosphere climate indices and their predictive ability were assessed using Pearson correlation and Akaike Information Criterion (AIC) stepwise regression method to select best climate indices at lagged timestep that fit the SPI. The SPI exhibited moderate to severe drought during the dry seasons. Accra exhibited a significant increasing SPI trend in JFM, NDJ, and DJF seasons. Besides, Saltpond during DJF, Tema, and Axim in NDJ season showed significant increasing trend of SPI. In recent years, SPIs in dry seasons are increasing, an indication of weak drought intensity, and the catchment areas are becoming wetter in the traditional dry seasons. Direct (inverse) relationship was established between dry seasons SPIs and Atlantic (equatorial Pacific) ocean's climate indices. The significant climate indices modulating drought SPIs at different time lags are a combination of either Nino 3.4, Nino 4, Nino 3, Nino 1 +2, TNA, TSA, AMM, or AMO for a given station. The AIC stepwise regression model explained up to $48 \%$ of the variance in the drought SPI and indicates Nino 3.4, Nino 4, Nino 3, Nino 1 + 2, TNA, TSA, AMM, and AMO have great potential for seasonal drought prediction over Coastal Ghana.
\end{abstract}

\section{Introduction}

Drought is a climate phenomenon on land where a given location experiences below normal precipitation. It can happen on a different timescale. The impacts of drought are visible in areas of agriculture, energy (hydroelectric production), and water resource management for both domestic and industrial use. To properly understand drought, four categories of drought exist depending on the physical impact on the environment [1]. They are agricultural, meteorological, hydrological, and socioeconomic drought. Agricultural drought occurs when there is lack of needed soil moisture for plant growth; meteorological drought reflects on lack of precipitation from the atmosphere. Socioeconomic drought deals with a lack of water supply for the society, whereas hydrological drought focuses on deficiency in the amount of surface and groundwater [2]. Based on the type of drought and its complexity, several analysis techniques have been developed to analyze them. These include Palmer Drought Severity Index (PDSI), Standardized Precipitation-Evapotranspiration Index (SPEI), Standardized Precipitation Index (SPI), and Normalized Difference Vegetation Index (NDVI) [3].

In sub-Saharan Africa, agriculture is predominantly rain-fed. The year-to-year variation of rainfall affects food security. Drought is a threat to agriculture in sub-Saharan 
Africa [4]. Studies have shown the devastating impact of drought on West Africa most especially over the Sahel region $[5,6]$. The Sahel region was plagued with prolonged drought periods for over a decade from $1970[7,8]$.

Several factors facilitate and influence drought occurrence. They can be triggered by anthropogenic or natural processes. Ocean-atmosphere mechanism is a natural process that contributes to drought occurrence on spatiotemporal timescales [9]. Variability of drought due to ocean-atmospheric mechanisms is triggered by changes in anomalous sea surface temperatures (SSTs) and sea-level pressure (SLP) of remote ocean-atmospheric teleconnection. The ocean's unique features of high heat capacity and memory are major drivers of global and African climate systems [10]. The role of SSTs and associated remotely forced phenomena on West Africa, Sahel, East Africa, and Southern Africa's climate has been investigated [11, 12]. Key teleconnection factors linked to the rainfall over Africa are North Atlantic Oscillation (NAO), El Niño Southern Oscillation (ENSO), Atlantic Meridional Mode (AMM), and Atlantic Multidecadal Oscillation (AMO), among others. On drought, ENSO is known to have played a significant role in contributing to drought occurrence at different timescales in the US and Columbia [13-15]. In West Africa, the prolonged drought situation in the Sahel was connected to the influence of large ocean-atmosphere climate indices like ENSO, AMO, and Tropical Atlantic Oceanic indices [16].

Although studies done on drought in West Africa have primarily focused on Sahel, on a country scale, little of such studies have been done over Ghana. Ghana, a country within the West Africa subregion, had its share of the drought menace in the 1980s but was not on a scale as the Sahel [17]. Climatologically, the country has a dry and rainy season, bimodal rainfall season in the south, and unimodal season in the north of the country $[18,19]$. Precipitation over Ghana is largely driven by the position of the Intertropical Discontinuity (ITD) which determines the seasonal cycle of rainfall. The ITD forms when two air masses of moist southwest trade winds meet with northeast trade winds. The dry air mass emanates from the Sahara Desert, and the moist air comes from the South Atlantic Ocean.

Ocean-atmospheric drivers of drought over Ghana are not clearly known. This hinders the effort of meteorologists or climate scientists in making projections on sub-seasonal to seasonal timescale. To address this gap, this study seeks to investigate meteorological drought and its trends, ascertain the impact of remote global ocean climate indices on drought, and understand its predictability. The fundamental understanding of mechanisms driving drought are critical to develop an early warning system for climate disaster risk management.

In this study, the statistical analysis techniques were adopted. They include computing three (3) months' Standardized Precipitation Index (SPI) of rainfall, seasonal Mann-Kendall trend test, correlation analysis, and Akaike Information Criterion (AIC) [20] stepwise regression between the SPI and the climate indices. This paper is arranged as follows: Section 2 gives a brief description of the study area, Section 3 highlights the data and methods, Section 4 presents the results and discussions, and Section 5 is the conclusion.

\section{Study Area}

Ghana is geographically located between latitude $4.5^{\circ} \mathrm{N}$ and $11.5^{\circ} \mathrm{N}$ and longitude $3.5^{\circ} \mathrm{W}$ and $1.5^{\circ} \mathrm{E}$ (Figure 1). The country has both dry and wet seasons. The latitudinal oscillation of the ITD mainly influences the climate of Ghana. Based on the climatological characteristics, there are four agroecological zones in Ghana. They are the coastal savanna, forest, transitional, and savanna zones. The focal area of the study is Coastal Ghana. Vegetations in Coastal Ghana are diverse with the East Coast classified under Coastal Savanna whereas the West Coast has a mixture of Deciduous Forest (DF) and Tropical Forest (TF) zone. The coastal savanna experiences relatively low rainfall for both major and minor rainy seasons. The West Coast is one of the wettest ecological regions of Ghana. The main economic activities of indigenes are trading, agriculture, and fishing. Coastal Ghana is within latitude $4.5^{\circ} \mathrm{N}$ to $t 6.5^{\circ} \mathrm{N}$, as shown in Figure 1 . The six synoptic stations are Axim (Lat. 4.87, Lon. -2.23), Takoradi (Lat 4.88, Lon. -1.77), Saltpond (Lat. 5.2, Lon. -1.07), Accra (Lat. 5.6, Lon. -0.17), Tema (Lat. 5.62, Lon. 0), and Ada (Lat. 5.78, Lon. 0.63).

Coastal rainfall season starts from March through to July and subsides in August (Figure 2). The month of August is usually termed as the little dry spell. The minor rainy season commences in September and ends in November. The dry season commences in late November to February (Figure 2). During the rainy season, most coastal stations experience more intense rainfall in June with maximum rainfall amount of $929.20 \mathrm{~mm}, 598.30 \mathrm{~mm}, 506.50 \mathrm{~mm}, 471.80 \mathrm{~mm}, 450 \mathrm{~mm}$, and $420 \mathrm{~mm}$, respectively for Axim, Ada, Takoradi, Saltpond, Tema, and Accra. Stations in the West Coast of Ghana (Axim, Takoradi, and Saltpond) have higher rainfall as compared to stations of the East Coast (Accra and Tema), although the characteristics of rainfall in Ada are like West Coast stations. The dry season occurs from November to March.

\section{Data and Methods}

3.1. Rainfall Data. Monthly daily rainfall data from six meteorological coastal synoptic stations of Ghana Meteorological Agency (GMet) were sourced for this study. The datasets were subjected to a quality control test to determine the percentage missing values and any outliers within the data. From the data quality analysis, the overall percentage missing values in the datasets were $2 \%$ or less for some stations. Duration of data used for the analysis spans from 1980 to 2014 (35 years).

3.2. Climate Indices. Climate indices are diagnostic quantities used to understand the current and future state of a climate system. Each of these indices was created to monitor an aspect of the climate system around the world. The indices are computed from data records of oceanic and 


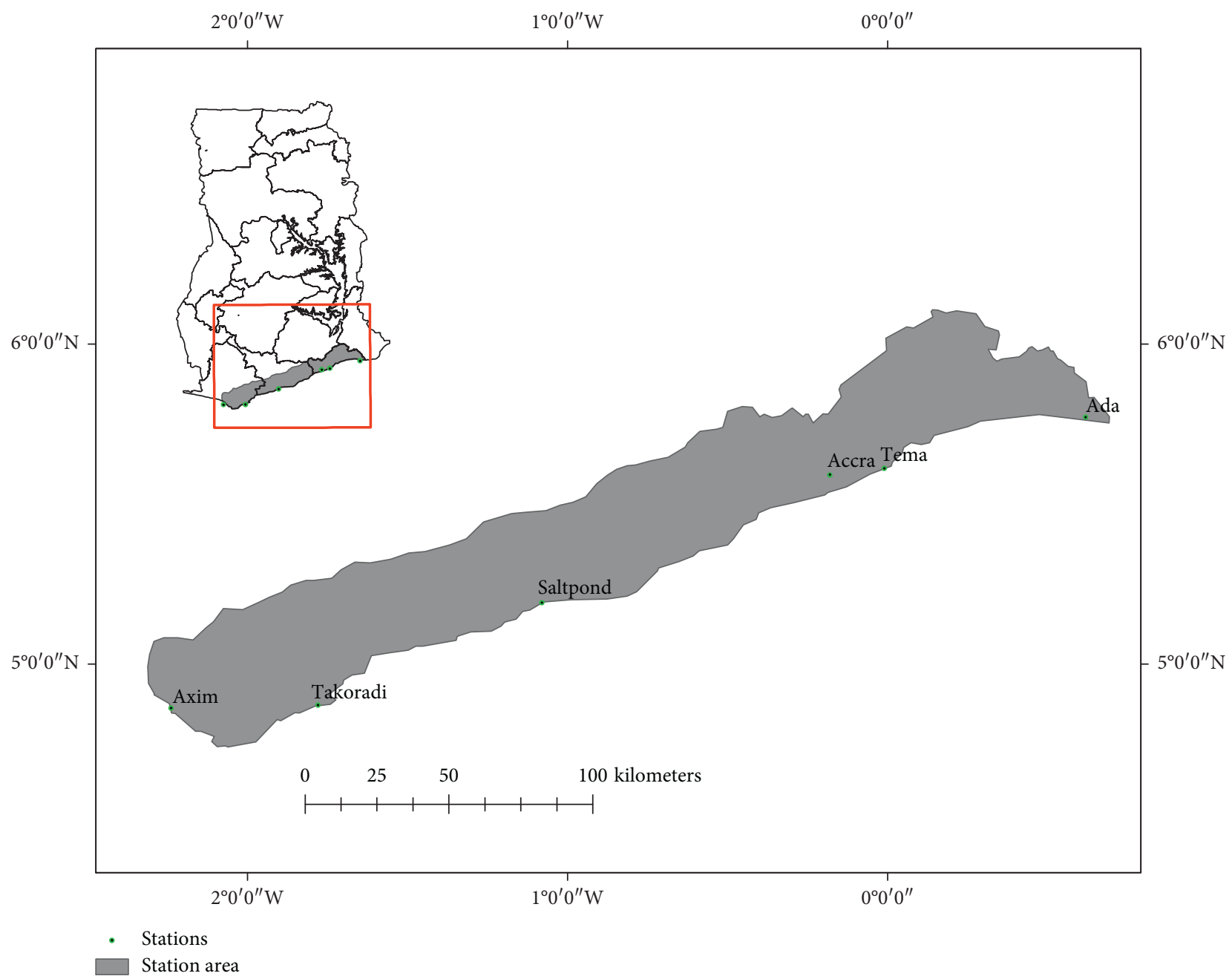

FIGURE 1: Study area highlighted from the map of Ghana with the six synoptic meteorological stations of Coastal Ghana.

atmospheric processes. Several of such indices have been developed, ten climate indices were selected to understand its linkages to meteorological drought over Coastal Ghana. The oceanic indices are based on SST anomalies over a given location and, in some instances, differences between SLP. The climate indices used for this study are Atlantic multidecadal oscillation (AMO), Niño $1+2$, Niño 3, Niño 3.4, and Niño 4, Atlantic Meridional Mode (AMM), Tropical North Atlantic (TNA), Tropical South Atlantic (TSA), North Atlantic Oscillation (NAO), and Southern Oscillation Index (SOI). AMO is derived by averaging SST anomaly over the North Atlantic Ocean within latitude $0-80^{\circ} \mathrm{N}$. The tropical Pacific indices are Niño $1+2$ of SST averages over latitude $0-10^{\circ} \mathrm{S}$ and $90^{\circ} \mathrm{W}-80^{\circ} \mathrm{W}$, Niño 3 index (average SST from $5^{\circ} \mathrm{N}$ to $5^{\circ} \mathrm{S}$ and $\left.150^{\circ} \mathrm{W}-90^{\circ} \mathrm{W}\right)$, Niño $3.4\left(5^{\circ} \mathrm{N}-5^{\circ} \mathrm{S}\right.$ and $\left.170-120^{\circ} \mathrm{W}\right)$, and Niño $4\left(5^{\circ} \mathrm{N}-5^{\circ} \mathrm{S}\right.$ and $\left.160^{\circ} \mathrm{E}-150^{\circ} \mathrm{W}\right)$. AMM is crossequatorial tropical Atlantic SST gradient within latitude $21^{\circ} \mathrm{S}-32^{\circ} \mathrm{N}$ and longitude $74^{\circ} \mathrm{W}-15^{\circ} \mathrm{E}$ [21], TNA $\left(5.5^{\circ} \mathrm{N}-23.5^{\circ} \mathrm{N}\right.$ and $\left.15^{\circ} \mathrm{W}-57.5^{\circ} \mathrm{W}\right)$, and TSA (Eq-20 $0^{\circ} \mathrm{S}$ and $\left.10^{\circ} \mathrm{E}-30^{\circ} \mathrm{W}\right)$. NAO is based on sea-level pressure difference between Azores High and the Subpolar Low; SOI is also SLP differences between Tahiti and Darwin, Australia. All the climate indices were sourced from the National Oceanic and Atmospheric Administration's (NOAA) Earth Systems Research Laboratory (ESRL) accessible at https://psl.noaa. gov/data/climateindices/list/. The data selected span from 1980 to 2014 .

3.3. Methods. The methods adopted for the study were Standardized Precipitation Index (SPI), Seasonal MannKendall test, correlation, and AIC stepwise regression.

3.3.1. Standardized Precipitation Index (SPI). The Standardized Precipitation Index [22] was developed to monitor precipitation anomalies such as droughts. SPI is used widely to monitor identified periods and duration of meteorological drought occurrence. The computation of SPI is done by using the long-term precipitation data and fitting it to gamma distribution and transforming to normal distribution. The gamma is expressed as the probability density function $[23,24] . R$ function spi from SPEI package was used for the computation [25].

It is mathematically expressed as 


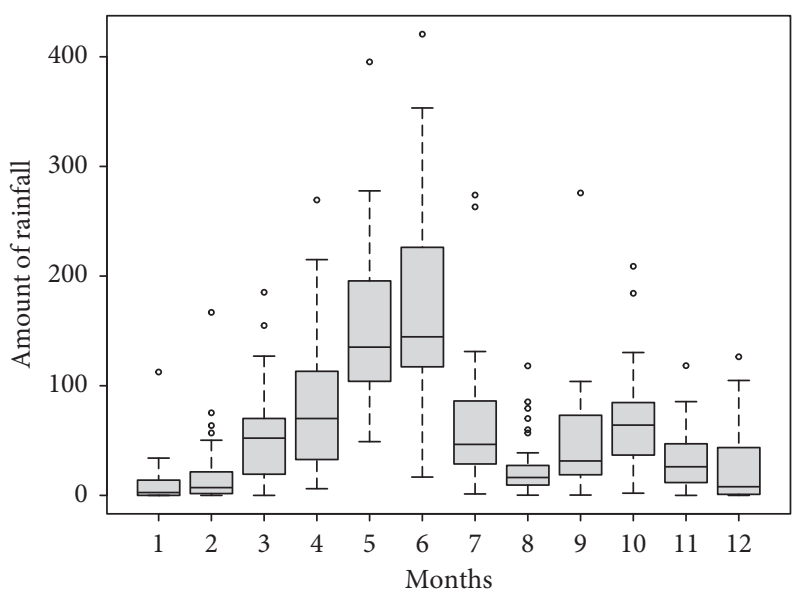

(a)

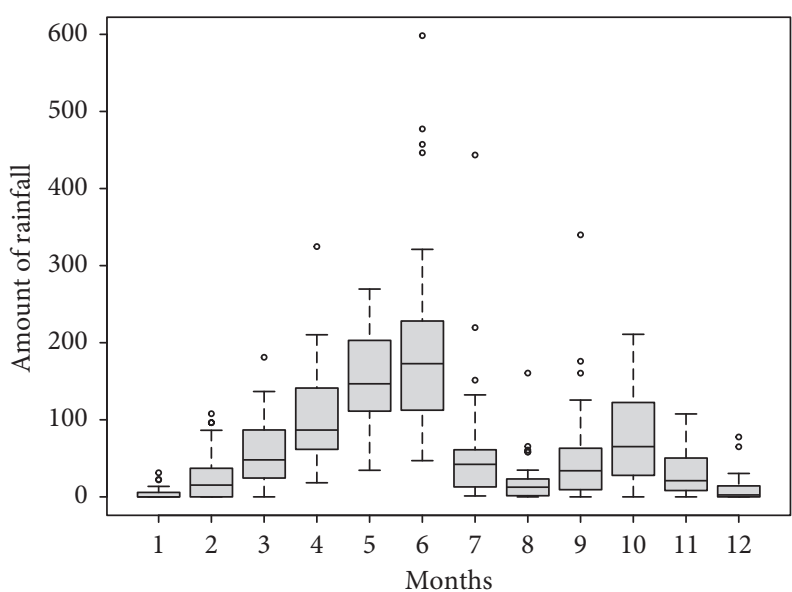

(c)

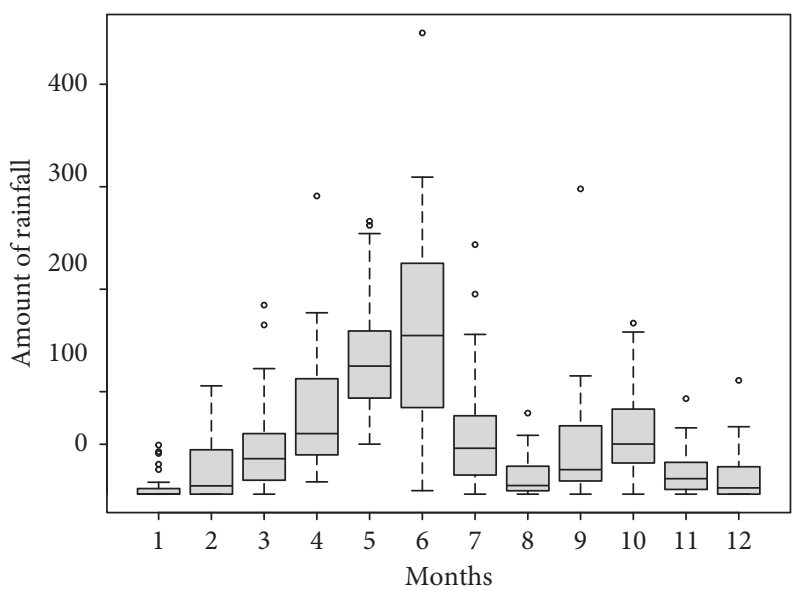

(e)

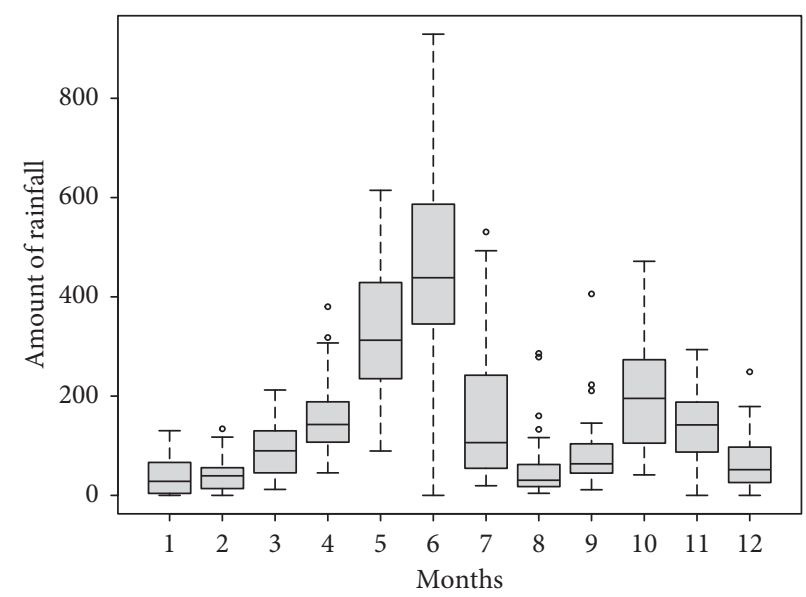

(b)

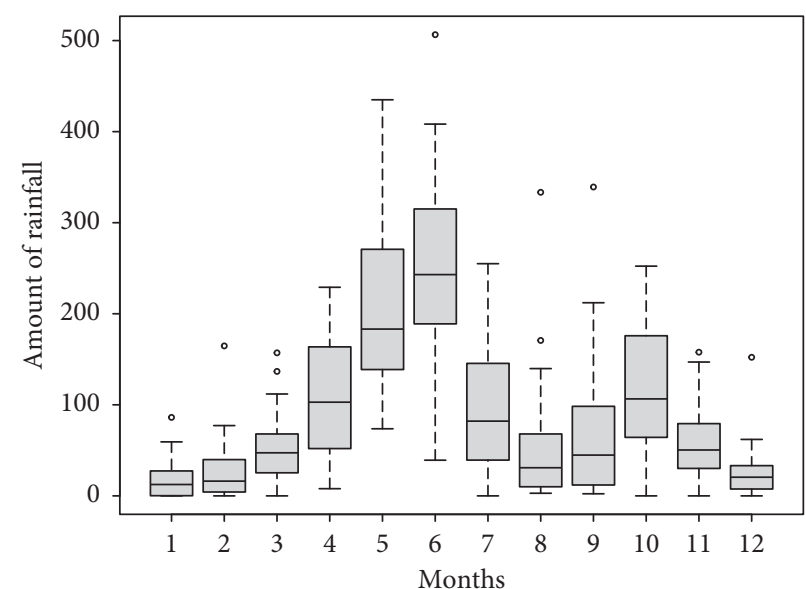

(d)

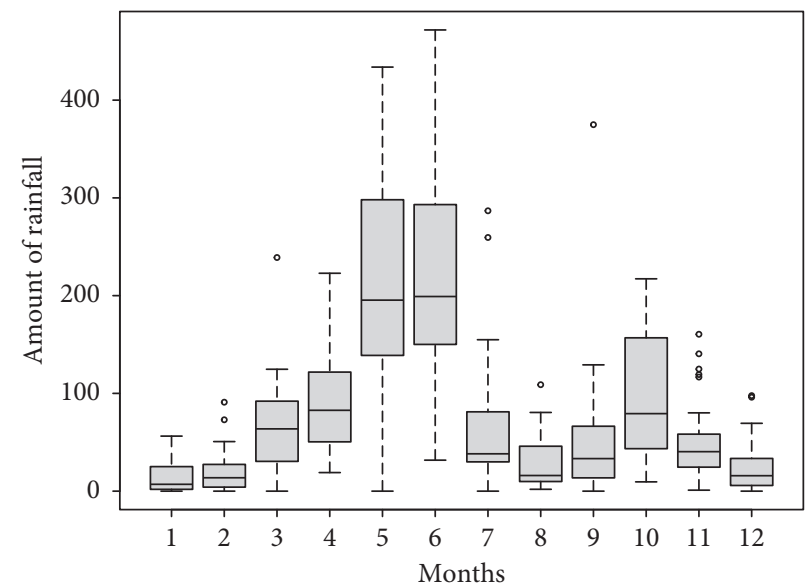

(f)

Figure 2: Boxplot showing monthly rainfall amount for (a) Accra, (b) Axim, (c) Ada, (d) Takoradi, (e) Tema, and (f) Saltpond meteorological stations from 1980 to 2014 .

$$
g(x)=\frac{1}{\beta^{a} \Gamma(a)} x^{a-1} e^{-(x / \beta)},
$$

where $a$ and $\beta$ represent the shape and scale parameters, $x$ is the precipitation amount, and $\Gamma(a)$ is the gamma function.
The estimation of Maximum Likelihood of $a$ and $\beta$ is given as

$$
a=\frac{1}{4 A}\left[1+\sqrt{1+\frac{4 A}{3}}\right] \text {, }
$$


$\beta=\bar{x} / a$, where $A=(\bar{x})-\sum(\operatorname{In}(x)) / n, \quad n=$ number of observations.

In SPI computation, precipitation data can be aggregated for $1,3,6,12$, and 24 months. The study uses three (3) months' SPI for analysis because of its usefulness in the primary agricultural region [26] that highlights the available moisture conditions at a given period.

3.3.2. Seasonal Mann-Kendall Trend Test. The Mann-Kendall (MK) test determines the monotonic trend in the time series of the SPI indices [27, 28]. The original MK test can be expressed mathematically as

$$
S=\sum_{i=1}^{n-1} \sum_{j=k+1}^{n} \operatorname{sign}\left(x_{j}-x_{i}\right)
$$

Note that whenever $S>0$, then later observations in the time series tend to be larger than those that appeared earlier in the time series, while the reverse is true if $S<0$.

The variance of $S$ is given by

$$
\sigma^{2}=\frac{\left\{n(n-1)(2 n+5)-\sum_{j=1}^{p} t_{j}\left(t_{j}-1\right)\left(2 t_{j}+5\right)\right\}}{18},
$$

where $\sigma^{2}$ is the variance and $t_{j}$ are the sets of data points in $j$ th term. The statistic $S$ is approximately normally distributed with

$$
z=\frac{S}{\sigma}=\left\{\begin{array}{cc}
\frac{(S-1)}{\sigma}, & S>0, \\
0, & S=0, \\
\frac{(S-1)}{\sigma}, & S<0 .
\end{array}\right\}
$$

$S$ is also related to Kendall's $\tau$ in the expression. $\tau=S / D$, tau $(\tau)$ indicates the magnitude of the trend and $D$ is given as

$$
D=\left[\frac{1}{2} n(n-1)-\frac{1}{2} \sum_{j=1}^{p} t_{j}\left(t_{j}-1\right)\right]^{1 / 2}\left[\frac{1}{2} n(n-1)\right]^{1 / 2} .
$$

The 95\% confidence level was used to determine the significance of the trend analysis. If $z$ is significant, the observed trend is significant and vice versa. Sen's nonparametric method [29] was also used to estimate the magnitude of trends.

The null hypothesis of the original MK test was based on independent and randomly distributed data with no seasonality and serial correlation in the data. Once seasonality or serial correlation is present, using original MK may lead to false identification of trends [30]. In this study, the JFM, NDJ, and DJF SPI data are seasonal but the autocorrelation in time series [31] was tested which proved insignificant. Hence, the seasonal MK test proposed by [32] to eliminate the effect of seasonality was used for the trend analysis. The seasonal Mann-Kendall trend test is expressed as

$$
\begin{aligned}
& s_{g}=\sum_{i<j} \operatorname{sign}\left(x_{j g}-x_{i g}\right), \quad g=1,2, \ldots p, \\
& S^{\prime}=\sum_{g-1}^{p} S_{g} .
\end{aligned}
$$

The variance of $S^{\prime}$ is given as

$$
\operatorname{Var}\left(S^{\prime}\right)=\sum_{g} \sigma_{g}^{2}+\sum_{g, h(g \neq h)} \sigma_{g h}
$$

where $\sigma_{g}^{2}=\operatorname{Var}\left(S_{g}\right) ; \sigma_{g h}=\operatorname{Cov}\left(S_{g}, S_{h}\right)$.

3.3.3. Correlation. To establish the relationship between the global climate indices and the SPI, the Pearson correlation was computed at a significance level of $5 \%$. The multiple correlation between dry seasons SPIs, both concurrent and lagged seasonal climate indices, was done using $r \operatorname{corr}()$ function [33] from $R$ Hmisc package. Seasonal composite of SPI was computed by averaging three consecutive months' SPI: annual seasonal cycles of January-February-March (JFM), February-March-April (FMA), March-April-May (MAM), April-May-June (AMJ), May-June-July (MJJ), June-July-August (JJA), July-August-September (JAS), August-September-October (ASO), September-OctoberNovember (SON), October-November-December (OND), November-December-January (NDJ), and December-January-February (DJF). The dry seasons which were the focus of the SPIs are JFM, NDJ, and DJF.

3.4. Stepwise Regression. Stepwise regression fits the best regression models to the observed SPI by choosing the best models of predictive variables (climate indices) based on specific criteria. The stepwise regression was based on AIC criteria [20]. First, multiple regression (MR) analysis was done to filter statistically significant climate indices that fit the station's SPI as predictant $[34,35]$. The regression model can be represented mathematically as

$$
y=\beta_{0}+\beta_{1} x_{1}+\beta_{2} x_{2}+\beta_{3} x_{3}, \ldots,+\beta_{i} x_{i}+\varepsilon,
$$

where $y$ is the SPI (dependent variable), $x_{1}, x_{2}, \ldots, x_{i}=$ climate indices (independent variables), $\beta_{0}=$ intercept of regression model, $\beta_{1}, \beta_{2}, \ldots, \beta_{i}=$ coefficients of predictors, and $\varepsilon=$ error margin.

Once the multiple regression is done, the AIC criteria for selection of best fit model are done. The stepAIC() function from the MASS $R$ package [36] based on both forward and backward steps was used for the analysis. The results with minimum AIC values had the best goodness of fit and, hence, maintained to fit the model.

\section{Results and Discussion}

4.1. Drought Characterization in Coastal Ghana. The meteorological drought over Coastal Ghana was characterized based on the SPI classification shown in Table 1. Periods with SPI index less than zero are classified as drought periods. Three months' SPI analysis over Coastal Ghana indicates 
TABLE 1: SPI classification.

\begin{tabular}{lc}
\hline SPI & Classification \\
\hline 2.00 or more & Extremely wet \\
1.50 to 1.99 & Severely wet \\
1.00 to 1.49 & Moderately wet \\
0 to 0.99 & Mildly wet \\
0 to -0.99 & Mild drought \\
-1.00 to -1.49 & Moderate drought \\
-1.50 to -1.99 & Severe drought \\
-2 or less & Extreme drought \\
\hline
\end{tabular}

Coastal Ghana experienced mild to severe (Figure 3) drought over the years. Major historic drought periods observed are 1983 to $1984,1988,1993,1997$ to 1998,2000 to 2001, 2009, and 2012-2013 for most coastal stations. The drought periods identified in the present study corroborate with some severe drought events identified in West Africa, Volta basin, and Sahel [37-40].

Another important observation for Accra, Tema, Ada, and Saltpond indicates, beyond 2005, these stations experienced very short drought periods and less drought extreme conditions (see Figure 3). The behaviour of the SPIs suggests the stations are becoming wetter after 2005. Stations within the West Coast (Axim and Takoradi) during the same period are experiencing moderate drought conditions in recent years.

Drought conditions as shown in the SPI results exhibited interannual variations with moderate to severe drought conditions occurring nearly every half a decade for all stations (Figure 3). The SPI further suggests, drought in recent years does not last long for most stations.

4.2. Dry Seasons SPIs. The study focuses on the dry seasonal composites of JFM, NDJ, and DJF to understand the trend and pattern of dry seasons SPIs. The dry seasons in Ghana are mostly characterized by dry dusty northeast trade winds emanating from the Sahara Desert to the Gulf of Guinea which makes the atmosphere dry and results in meteorological drought.

4.2.1. JFM. In JFM, the season is characterized by drought based on the SPI classification. During this season, all coastal meteorological stations exhibit mild to moderate drought occurrence (Figure 4(a)). The pattern of SPI suggests from 2010 SPI increased for stations like Accra, Tema, and Ada. Accra indicates an increasing SPI during the period of study. Accra shows a significant increasing trend for the period of study. Stations like Saltpond and Tema depict positive tau and Sen's slope; nevertheless, the overall trend from 1984 to 2014 was not significant (Table 2). There is an indication that the intensity of drought over these stations is becoming weaker over the years; hence, coastal Ghana is becoming wetter during this season.

4.2.2. DJF. During boreal winter (DJF), SPI showed mild to moderate drought conditions for all stations (Figure 4(c)) apart from Axim which had some severe drought conditions from 1983 to 1987 and 2009. The pattern of SPI for Accra and Saltpond had a significant increasing trend with tau of 0.28 and 0.24 and Sen's slope of 0.016 and 0.011 , respectively (Table 3). Tema and Ada showed a rising SPI from 2005 to 2014 but the overall trend was not significant. The drought SPI demonstrated interannual variability.

4.2.3. NDJ. NDJ SPI demonstrates interannual variability with Accra, Axim, and Saltpond having significant increasing monotonic trend (Table 4). The overall trend of stations like Tema and Takoradi was not significant but SPIs of recent years are gradually increasing. There is an indication that Accra, Saltpond, Tema, and Takoradi stations are having more wetter conditions in recent years (Figure 4(b)).

Ada is becoming dryer in recent years with SPI decreasing. In general, meteorological stations in the West Coast of Ghana including Axim, Saltpond, and Takoradi showed signals of weaker drought SPI (see Figure 4(b)). During the NDJ season, the West Coast is becoming moist and drought conditions are becoming weaker.

4.3. Impact of Oceanic Indices on Drought Variability. The relationship between the drought SPI and multiple climate indices was established using multiple correlation analysis and AIC stepwise regression. The correlation analysis was done for both concurrent and lagged seasons of the SPI. The AIC penalizes the predictors to select the best fit model of observed SPI. Climate indices that satisfy this AIC criteria were retained and used for the predictive model. Dry seasons SPIs were the focus of the AIC stepwise regression by using the first and second lagged timestep of each SPI season's corresponding climate indices.

4.3.1. Relationship between Drought SPI and Climate Indices. The significant correlation between the dry season SPI, concurrent, and lagged time scale climate indices indicates the NDJ SPI significantly showed positive correlation with AMM ( $r=0.34$ to 0.39$)$, AMO ( $r=0.36$ to 0.42$)$, and TSA $(r=0.34$ to 0.43$)$ on most timescale. The lagged summer season NAO ( $r=-0.37$ to -0.48$)$ depicts an inverse relationship with NDJ SPI. Boreal winter (DJF) Nino $1+2$, Nino 3, Nino 3.4, and Nino 4 were negatively correlated with NDJ, JFM, and DJF SPIs with correlation coefficient between -0.3 and -0.55 . In some instances, stations like Saltpond demonstrate a positive correlation with Nino 3 , Nino 3.4, and Nino $1+2$ with JFM SPI. In general, the correlation analysis established the important role played by Atlantic and the equatorial Pacific climate indices of AMM, AMO, NAO, TNA, TSA, Nino 1+2, Nino 3, Nino 3.4, and Nino 4 in modulating drought variability over Coastal Ghana. The results indicate low (high) phase of AMM, AMO, TSA, and TNA will lead to low (high) phase of SPI over Coastal Ghana resulting in dry (wetter) condition. The low (high) phase of ENSO indices, i.e., Nino 1+2, Nino 3, Nino 3.4, and Nino 4, implies high (low) SPIs along the Coast of Ghana. 


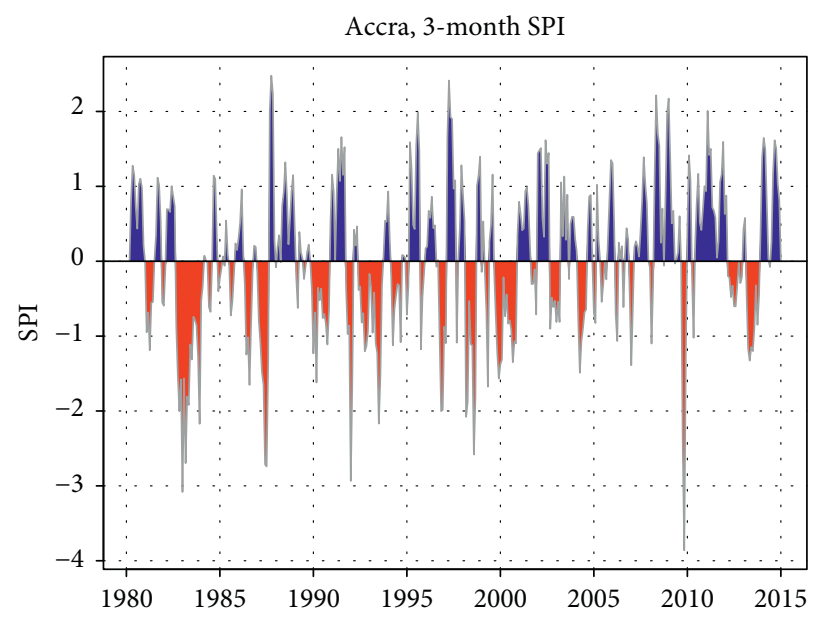

(a)

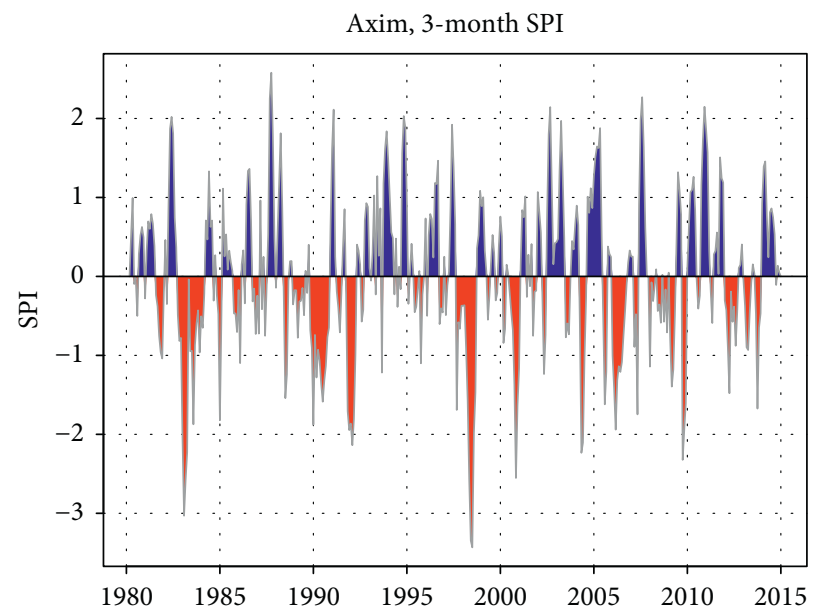

(c)

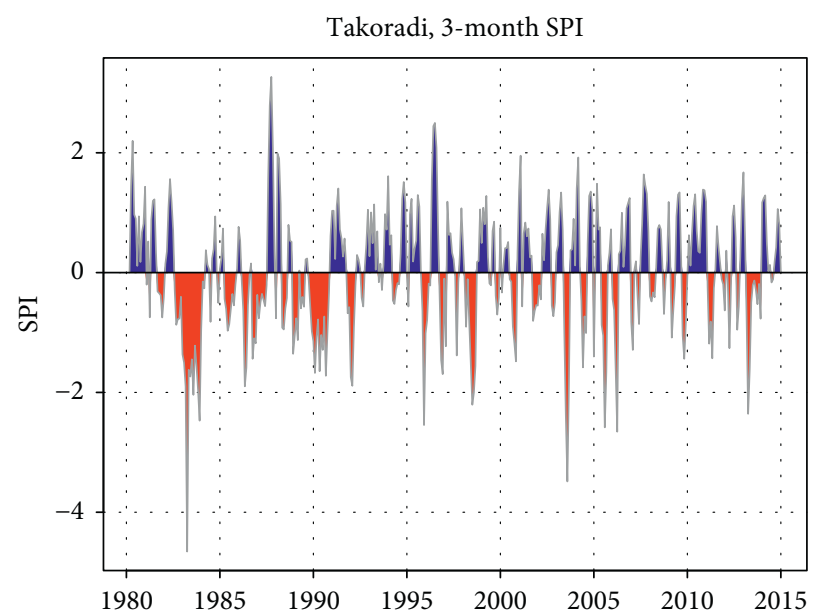

(e)

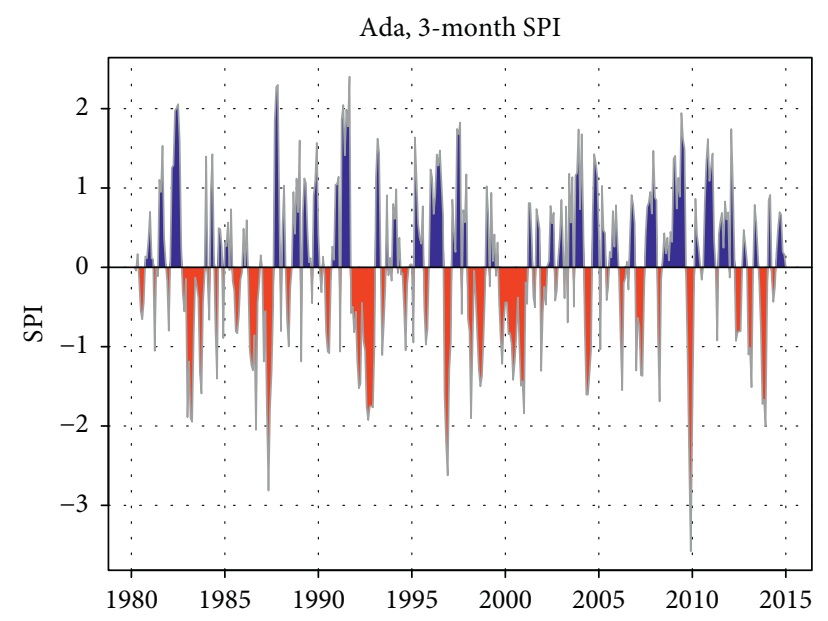

(b)

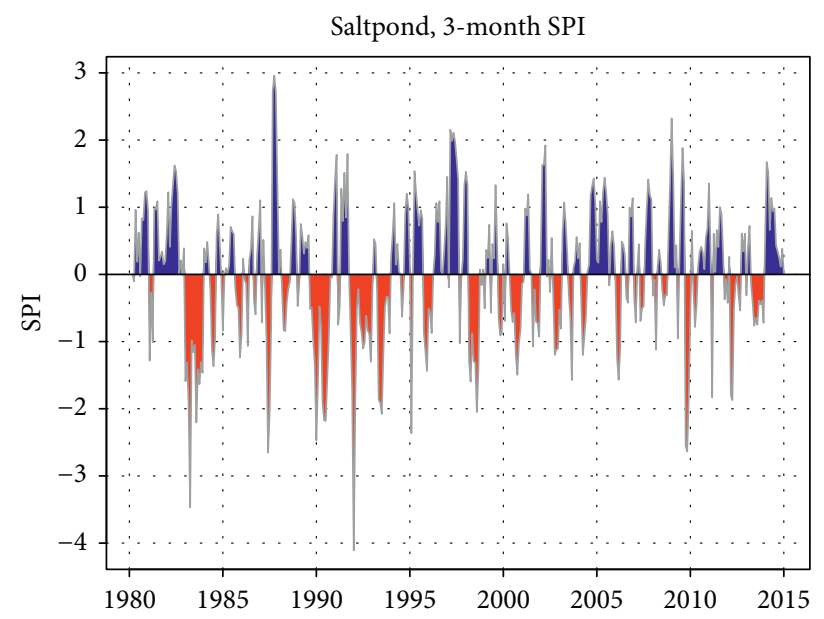

(d)

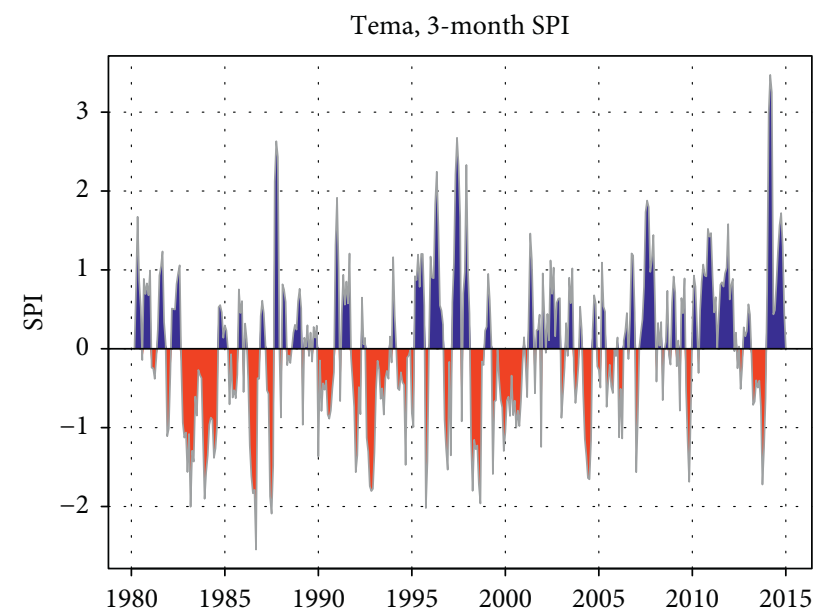

(f)

FIGURE 3: Three months' SPI of six synoptic coastal meteorological stations in Ghana from 1984 to 2014.

4.3.2. Predictability of Drought SPI. The stepwise AIC regression points to different combinations of climate indices from the Atlantic and equatorial Pacific oceans as having the combined effect of modulating and explaining some percentage variance in the drought SPI. A comparison of the output of the model and the observed SPI is shown in Figures 5-7. Majority of the fitted SPI models for the various stations were significant with $p$-value less than 0.05 . The predictive potential of these indices was determined by focusing on the first and second time lagged of NDJ, DJF, 

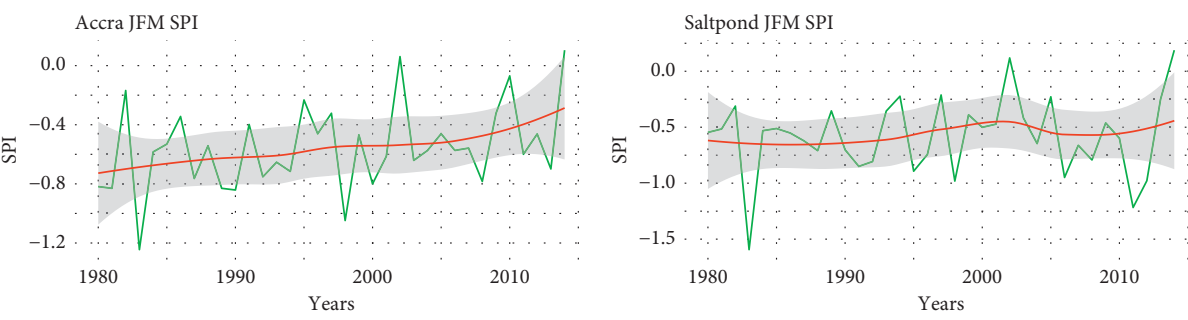

Tema JFM SPI
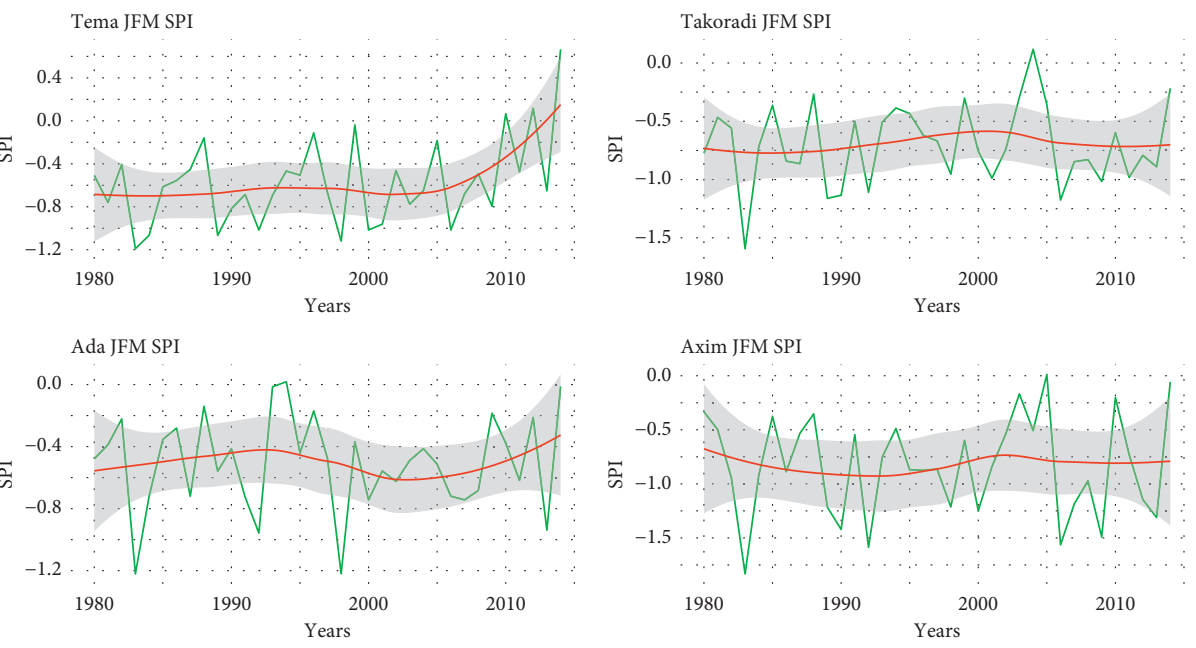

(a)
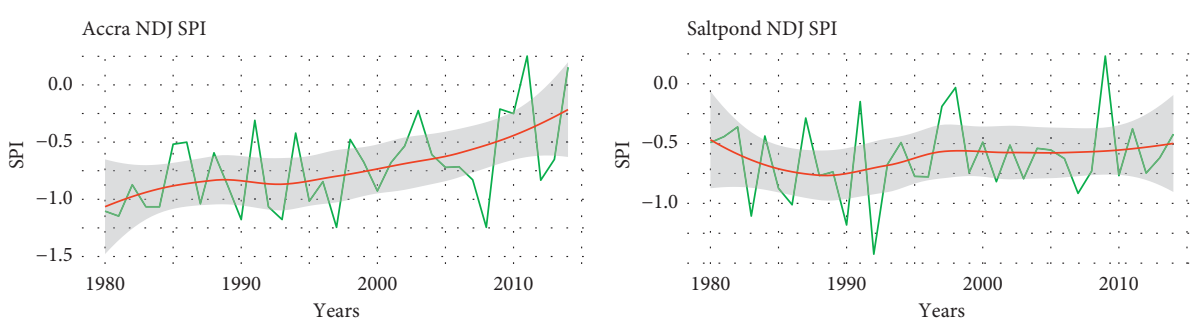

Tema NDJ SPI
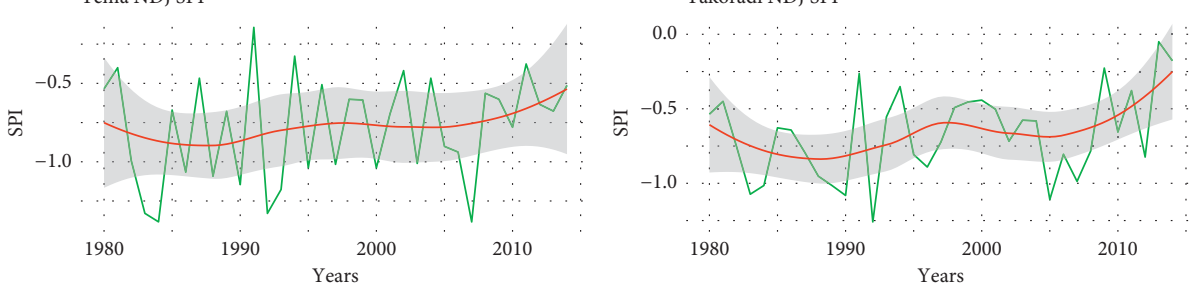

Ada NDJ SPI
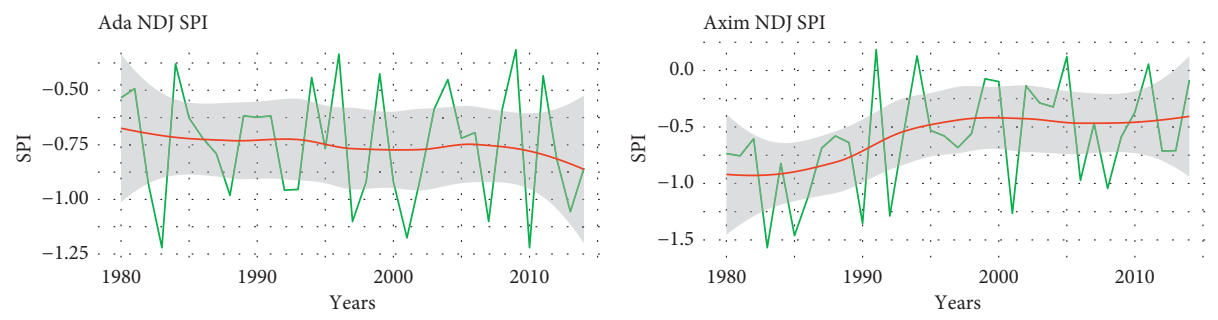

(b)

FIgURE 4: Continued. 

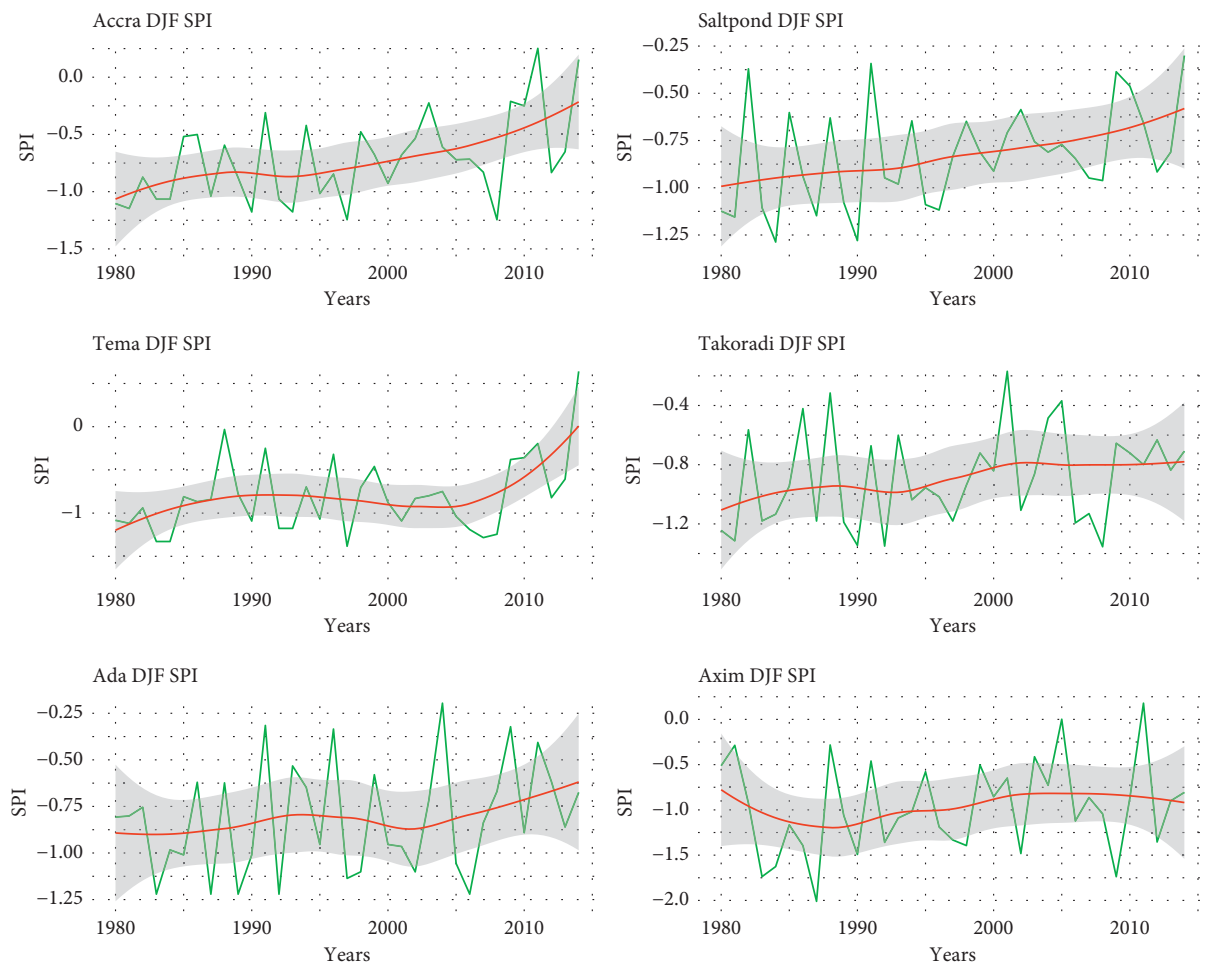

(c)

FIgURE 4: Time series analysis of JFM, NDJ, and DJF SPI for all six synoptic meteorological stations of Coastal Ghana.

and JFM dry seasons which are OND and SON for NDJ, NDJ and OND for DJF, DJF and NDJ for JFM. A comparison of fitted SPI from AIC stepwise regression and the observed SPI is shown in Figures 5-7.

The output of the stepwise regression analysis between lagged OND climate indices and drought SPI of NDJ shows combination of Nino 3, Nino 3.4, Nino 4, AMM, and NAO are the predictors that best fit the NDJ SPI of Accra with multiple R-square of 0.36 (Figure 5). NDJ SPI of Tema and Ada were significantly controlled by a combination of Nino 1+2, Nino 4, AMM, AMO, TNA, TSA, and SOI as shown in Table 5 explaining $41 \%$ and $42 \%$ of total variance for Tema and Ada, respectively. Nino 3.4 and TSA were the only predictors for Saltpond. The stepwise regression models of Accra, Tema, Ada, and Saltpond were significant (Table 5). The second lag season to NDJ, i.e., SON, indicates the model fit of Accra, Saltpond, Axim, and Tema were significant with multiple $\mathrm{R}$-square ranging from 0.20 to 0.36 with unique combinations of either AMO, Nino3.4, Nino 1 +2, Nino 4, AMO, AMM, TSA, or TSA.

AIC stepwise regression of boreal winter (DJF) seasonal SPI and NDJ climate indices exhibits that Nino 3, Nino 3.4, Nino 4, AMM, TNA, TSA, and NAO were the best predictors identified as forming the predictors to fit DJF SPI. The models fit explained between $21 \%$ and $48 \%$ of the variability in DJF season SPI (Table 6 and Figure 6 ). The model fit for all stations was significant except Tema. At the second lag season of OND, Accra was the only station with significant model fit that could explain 36\%
TABLE 2: JFM SPI modified Mann-Kendall test.

\begin{tabular}{lccc}
\hline Meteorological stations & Tau & Sen's slope & $p$ value \\
\hline Accra & 0.23 & 0.009 & $0.001^{*}$ \\
Ada & -0.03 & -0.001 & 0.83 \\
Axim & -0.005 & -0.001 & 0.97 \\
Saltpond & 0.01 & 4.958 & 0.93 \\
Takoradi & -0.002 & -0.0002 & 1.00 \\
Tema & 0.21 & 0.011 & 0.08 \\
\hline
\end{tabular}

Stations with * show significant trends.

TABLE 3: DJF SPI Mann-Kendall test.

\begin{tabular}{lccc}
\hline Meteorological stations & Tau & Sen's slope & $p$ value \\
\hline Accra & 0.28 & 0.016 & $0.02^{*}$ \\
Ada & 0.17 & 0.008 & 0.16 \\
Axim & 0.16 & 0.013 & 0.18 \\
Saltpond & 0.24 & 0.011 & $0.0001^{*}$ \\
Takoradi & 0.16 & 0.009 & 0.19 \\
Tema & 0.21 & 0.013 & 0.09 \\
\hline
\end{tabular}

Stations with ${ }^{*}$ show significant trends.

TABLe 4: NDJ SPI Mann-Kendall test.

\begin{tabular}{lccc}
\hline Meteorological stations & Tau & Sen's slope & $p$ value \\
\hline Accra & 0.29 & 0.016 & $0.02^{*}$ \\
Ada & -0.012 & -0.0007 & 0.85 \\
Axim & 0.27 & 0.018 & $0.028^{*}$ \\
Saltpond & 0.08 & 0.004 & $\mathrm{NA}$ \\
Takoradi & 0.20 & 0.010 & 0.09 \\
Tema & 0.17 & 0.009 & $0.016^{*}$ \\
\hline
\end{tabular}

Stations with * show significant trends. 

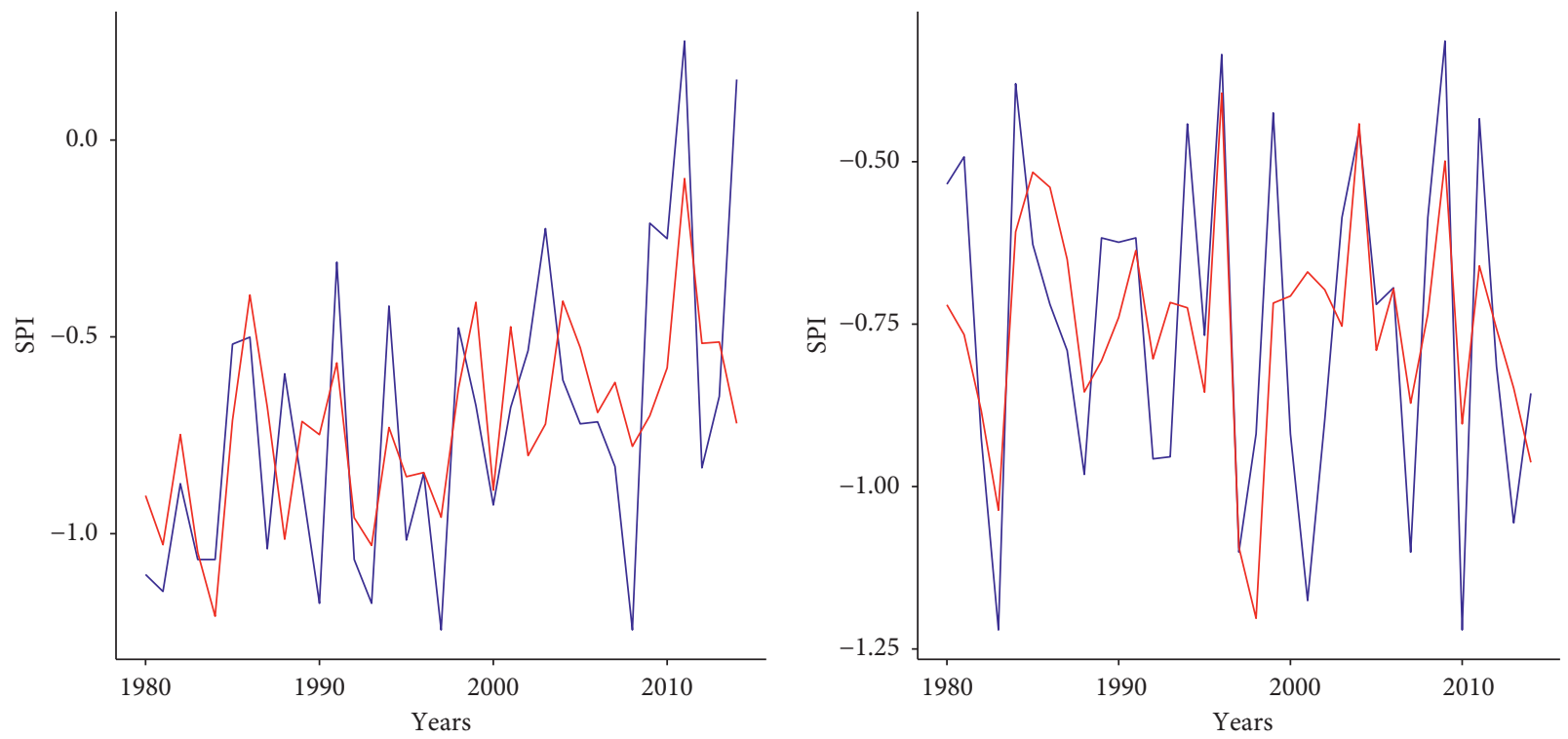

— Modeled SPI
- Observed SPI

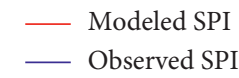

(a)
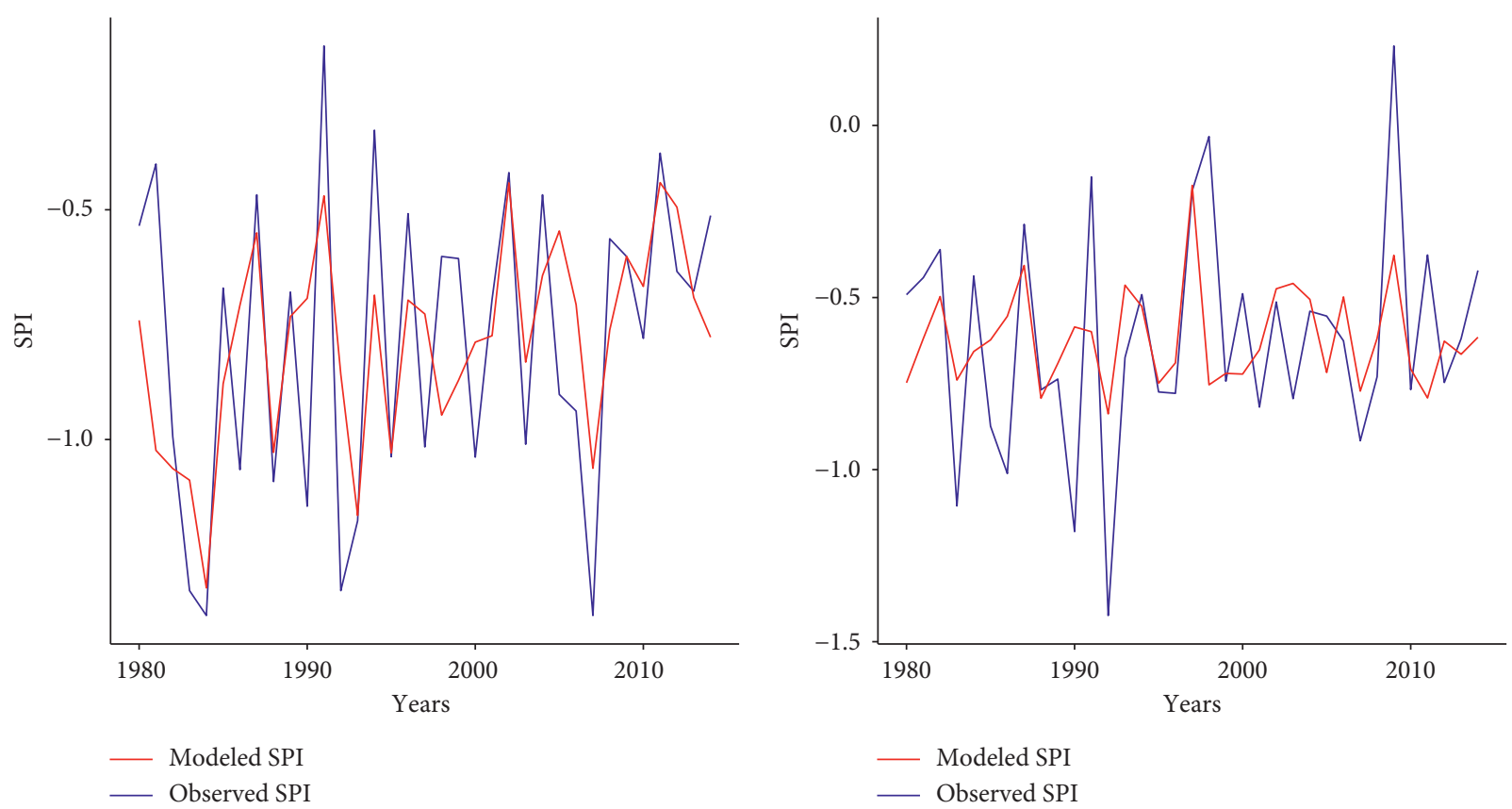

(c)

(d)

FIgure 5: Continued. 


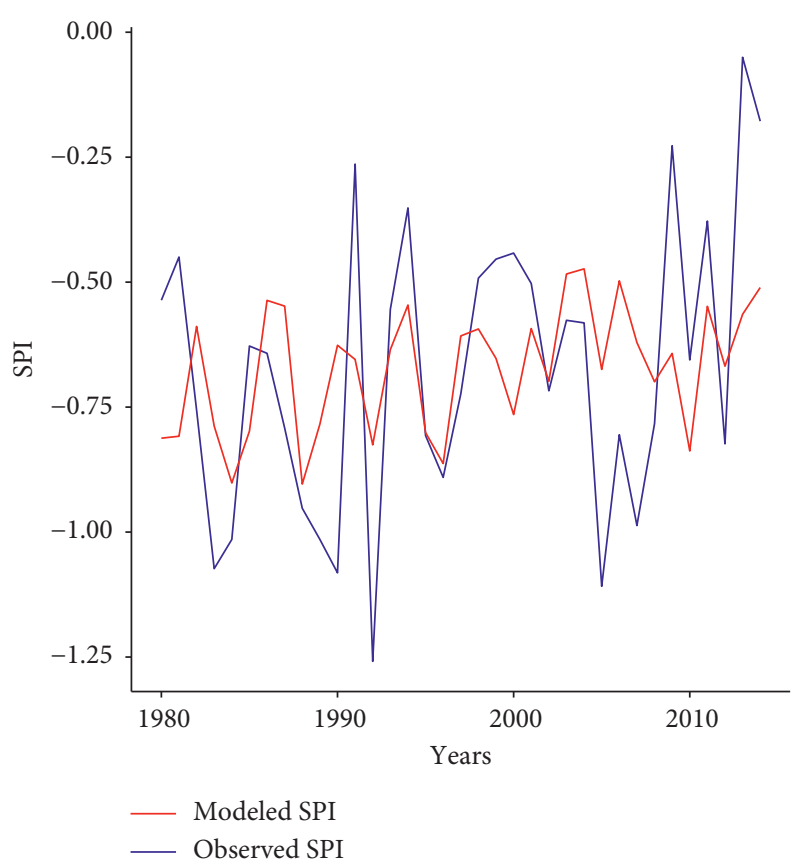

(e)

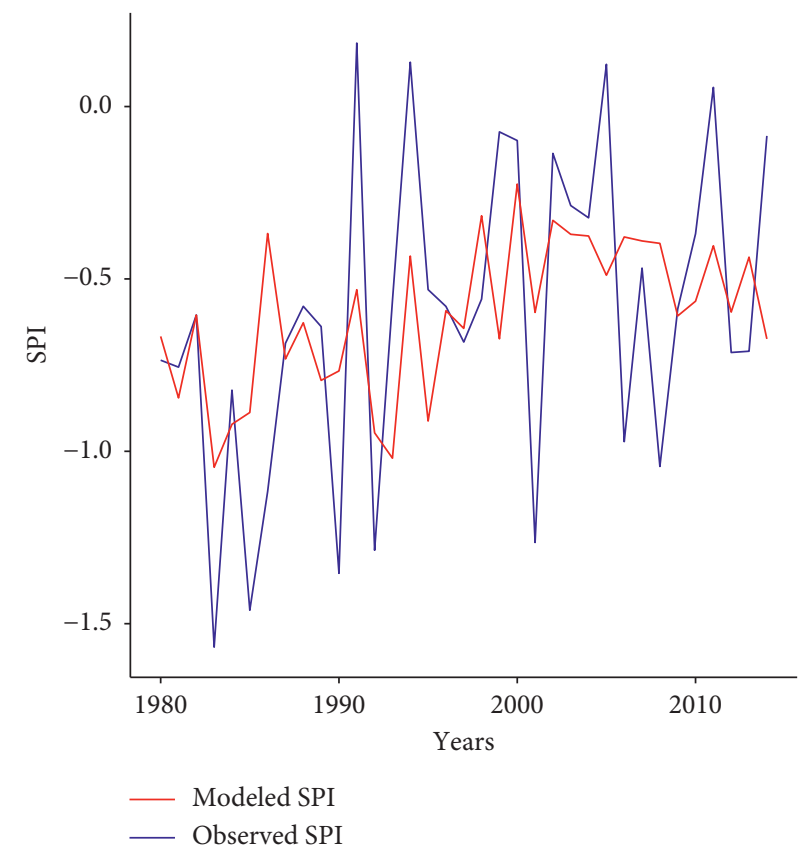

(f)

FIGURE 5: Comparison of modeled NDJ SPI based on OND climate indices versus observed NDJ SPI for (a) Accra, (b) Ada, (c) Tema, (d) Saltpond, (e) Takoradi, and (f) Axim meteorological stations at timescale of drought periods. The observed SPI is in blue and red is modeled.

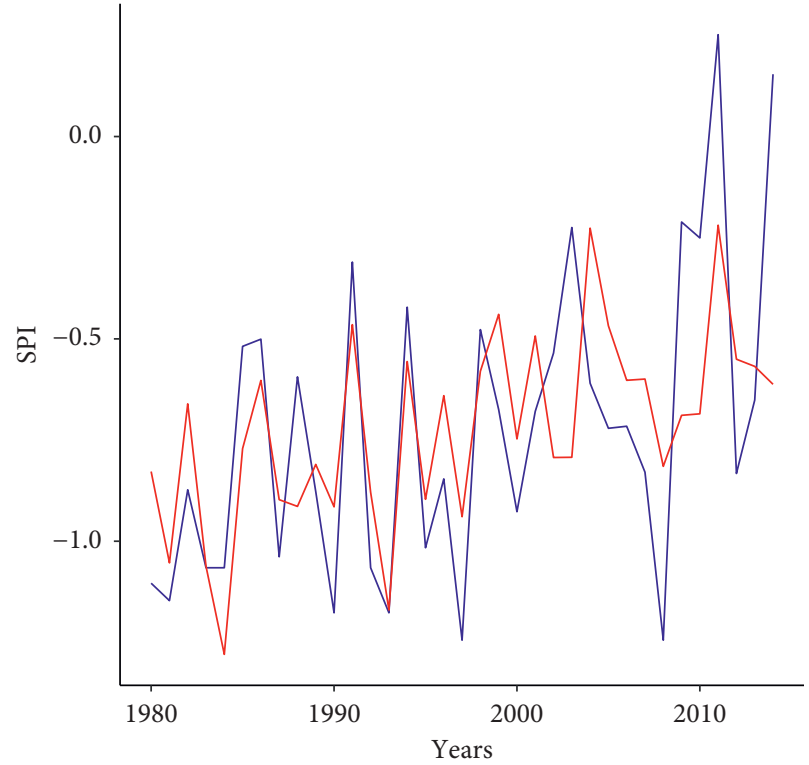

- Modeled SPI

- Observed SPI

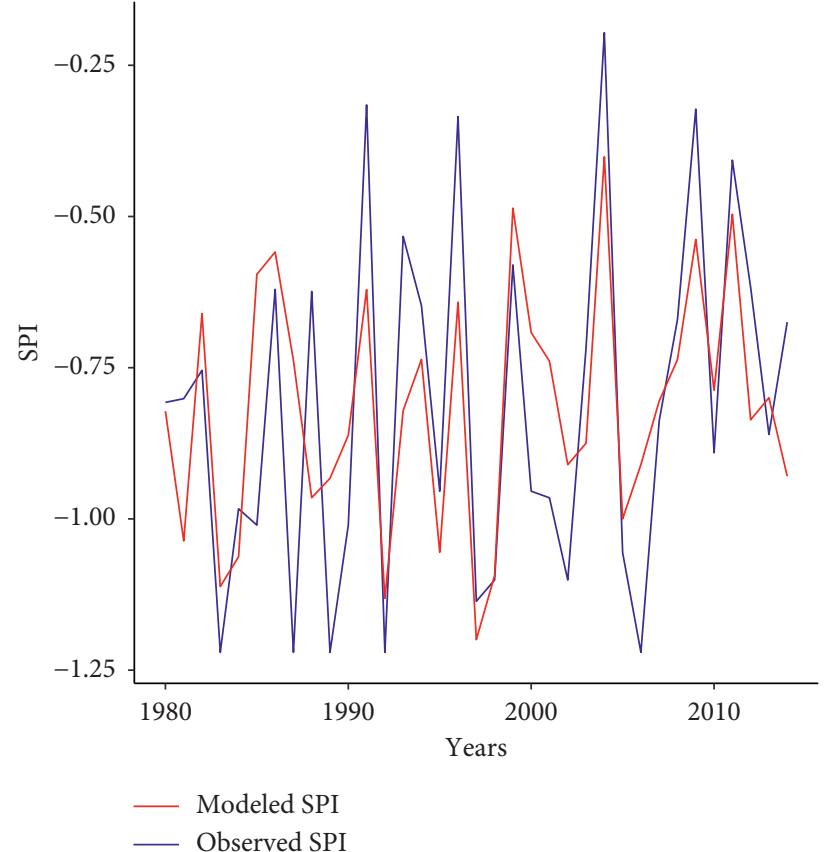

(b)

FIgURe 6: Continued. 


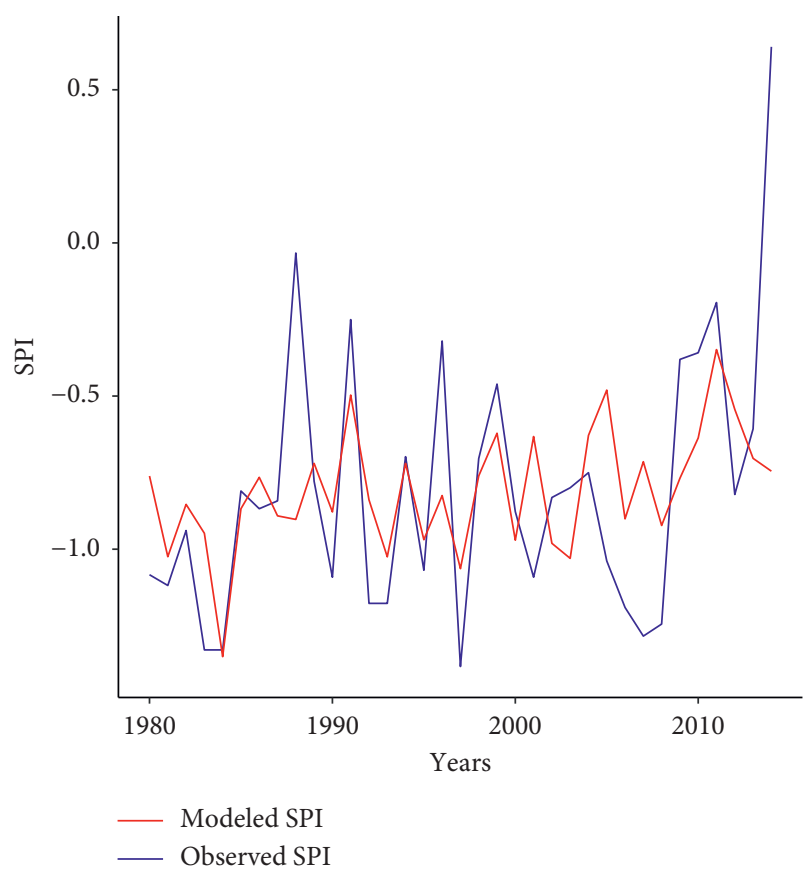

(c)

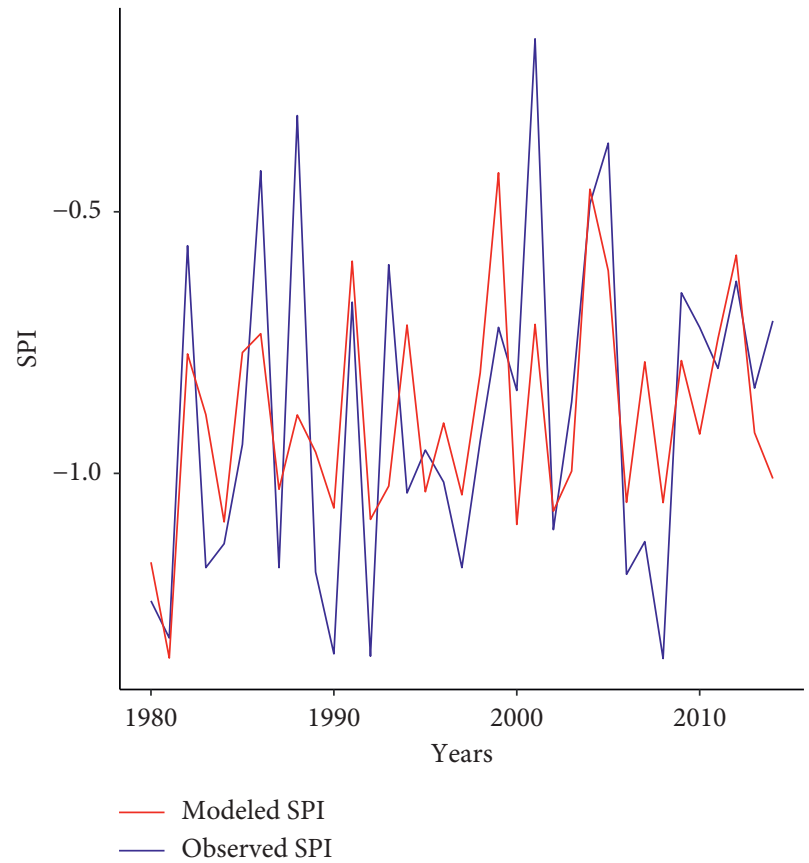

(e)

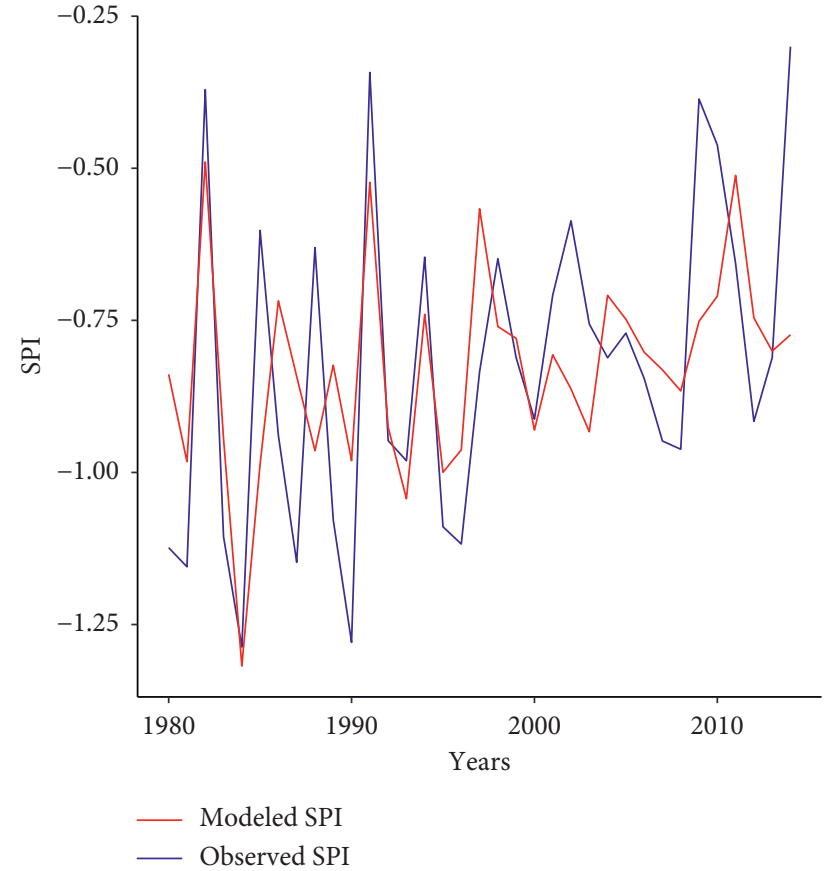

(d)

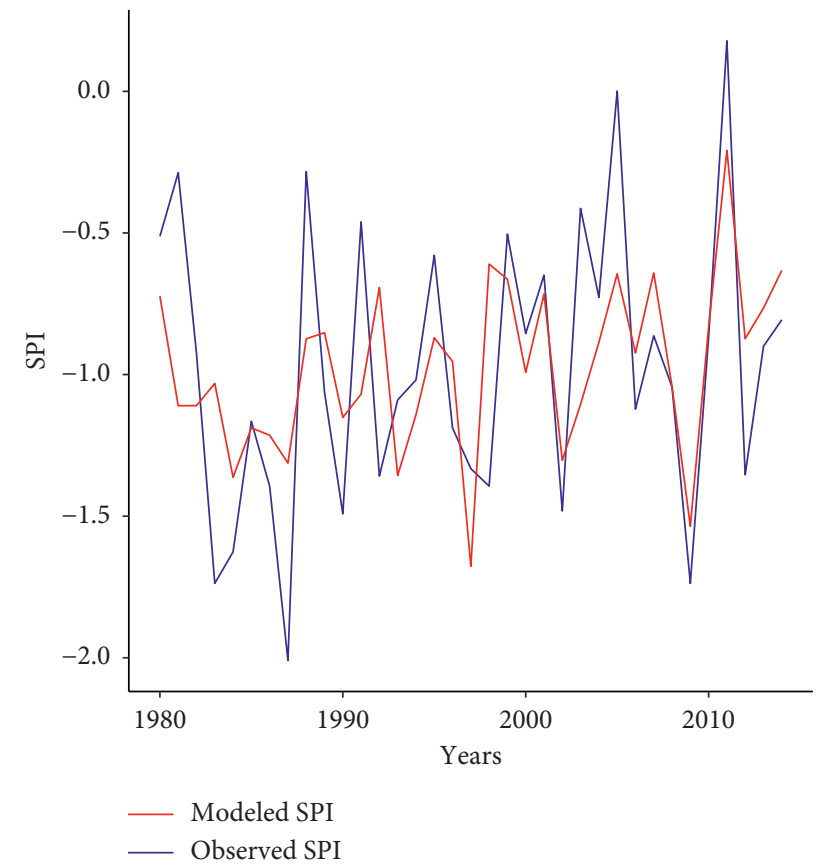

(f)

Figure 6: Comparison between modeled DJF SPI based on NDJ climate indices and observed DJF SPI for (a) Accra, (b) Ada, (c) Tema, (d) Saltpond, (e) Takoradi, and (f) Axim meteorological stations at timescale of drought periods. The observed SPI is in blue and red is modeled.

of DJF SPI variance. The climate indices that constitute the total model were like the identified climate indices of NDJ lagged season (see Figure 6 and Table 6).

The stepwise regression between JFM seasonal SPI and DJF climate indices also indicates Nino $1+2$, Nino 3, Nino 4, and Nino 3.4 are major drivers of JFM SPI
(Table 7). The DJF model fit of Accra, Saltpond, and Tema was significant, explaining 23 to $31 \%$ of total variance in JFM SPI. Axim did not show any of the climate indices having any connections with the SPI. The DJF lagged seasonal indices showed AMM, AMO, TSA, TNA, Nino 1+2, Nino 3, Nino 4, and Nino 3.4 indices as prominent 

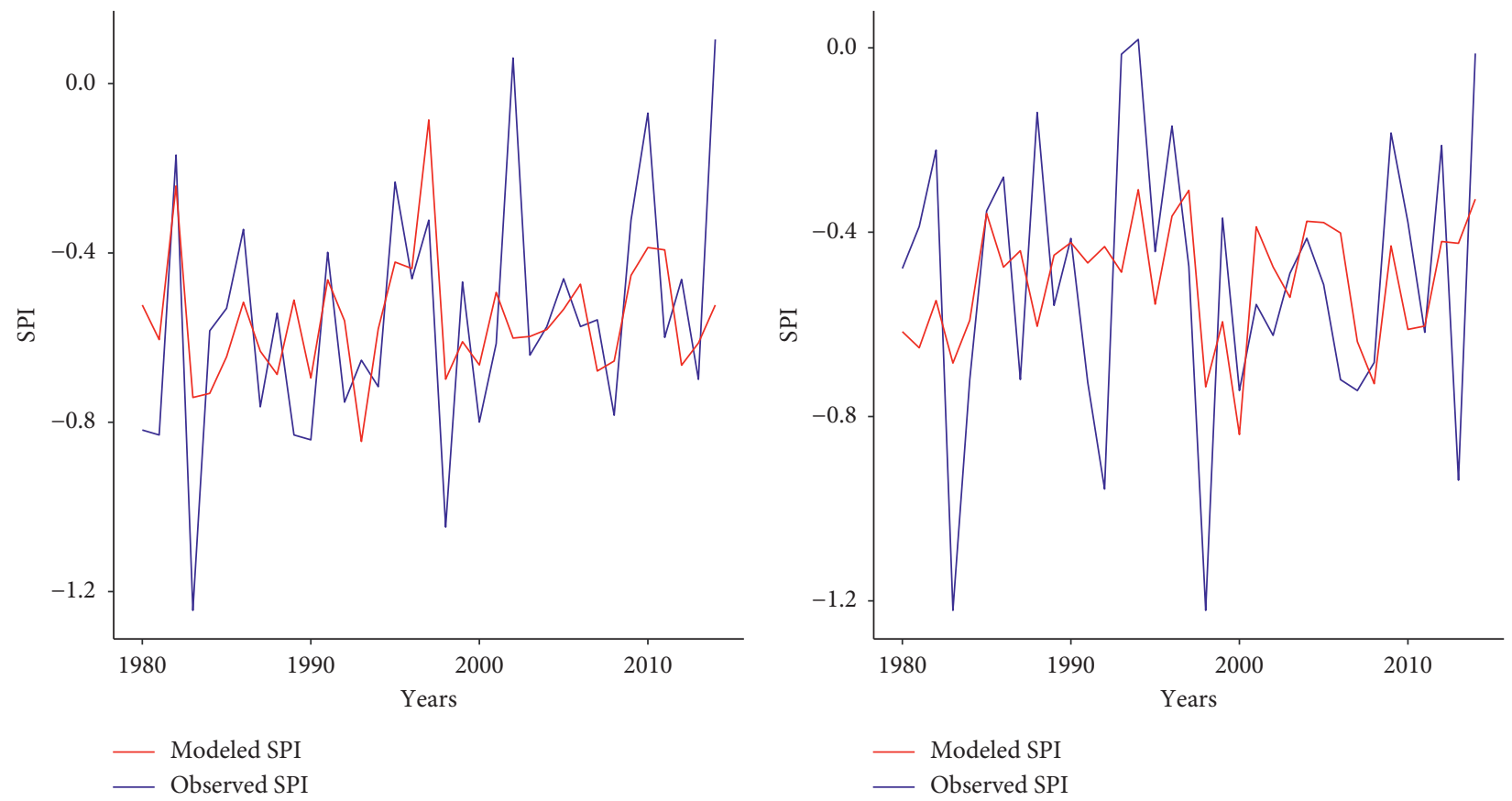

(a)

(b)
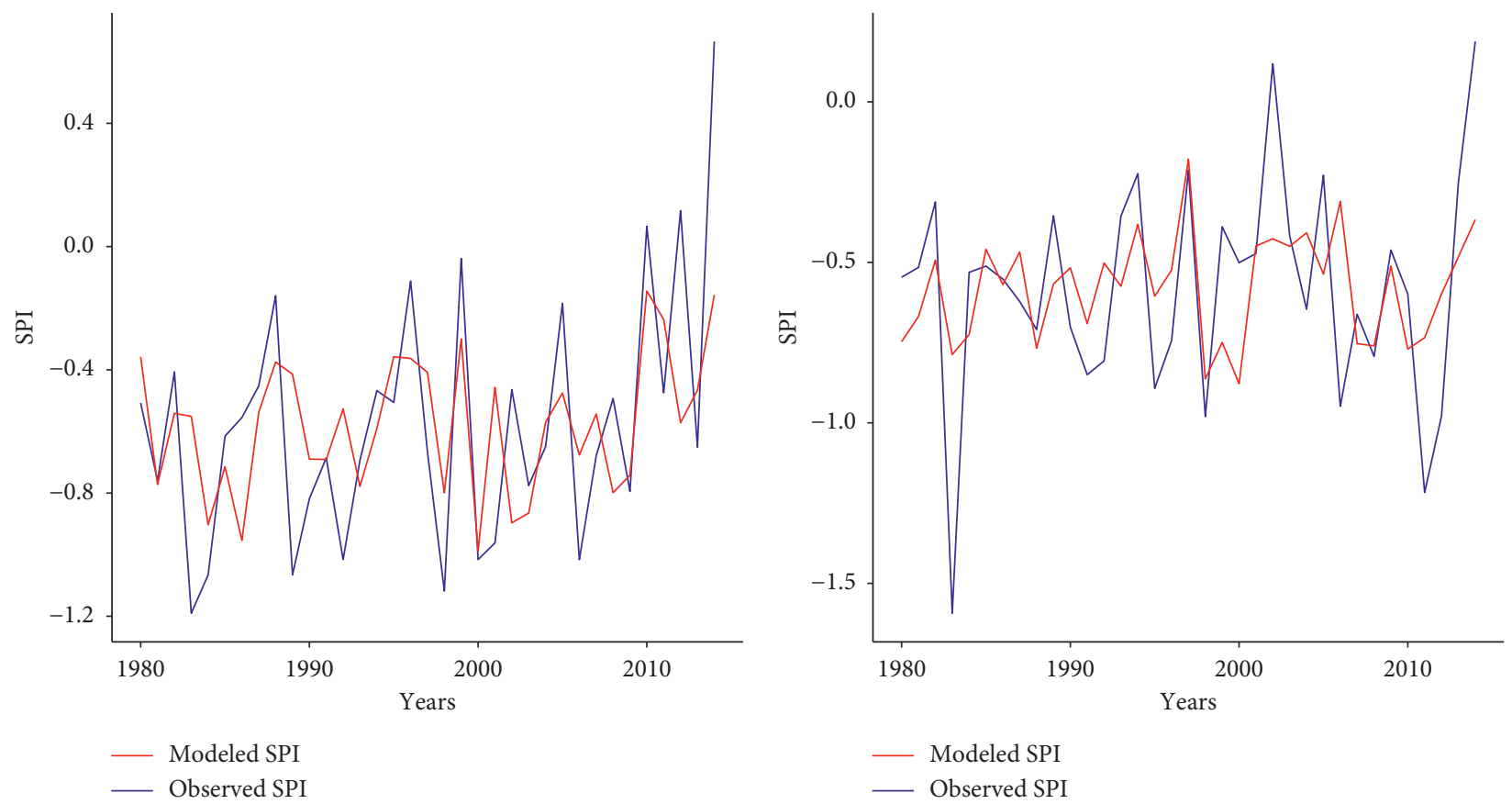

(c)

(d)

Figure 7: Continued. 


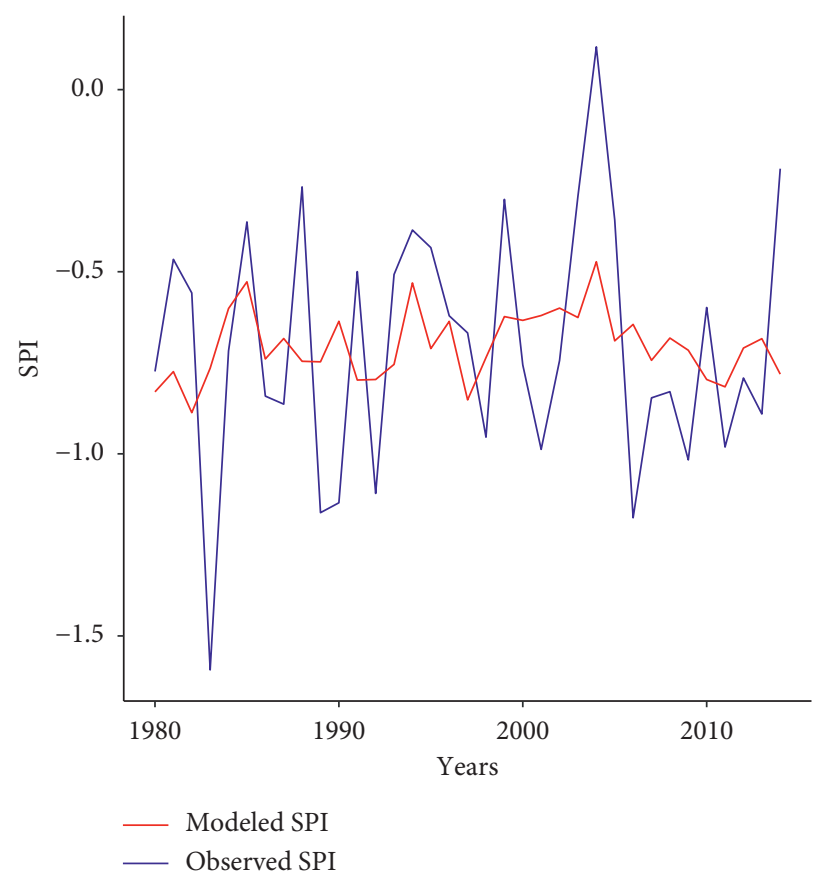

(e)

FIGURE 7: Comparison between modeled JFM SPI based on DJF climate indices versus observed JFM SPI for (a) Accra, (b) Ada, (c) Tema, (d) Saltpond, and (e) Takoradi meteorological stations at timescale of drought periods. The observed SPI is in blue and red is modeled.

TABLE 5: Summary of stepwise regression results between NDJ SPI and OND climate indices.

\begin{tabular}{lccc}
\hline Station & Predictor (s) & Multiple $R$-square & Adjusted $R$-square \\
\hline Accra & Nino 3, Nino 3.4, Nino 4, AMM, NAO & 0.36 & 0.25 \\
Ada & Nino 4, AMM, AMO, TNA, TSA, SOI & 0.42 & 0.30 \\
Saltpond & Nino 3.4, TSA & 0.19 & 0.14 \\
Axim & AMO, Nino 3.4, AMM, TNA, SOI & 0.23 & $0.011^{*}$ \\
Tema & Nino 1+2, Nino 3.4, Nino 3, AMM, TSA, SOI & 0.41 & $0.04^{*}$ \\
Takoradi & Nino 3.4, NAO, AMO & 0.19 & 0.17 \\
\hline
\end{tabular}

Stations with significant models are identified with *.

TABLE 6: Summary of stepwise regression results between DJF SPI and NDJ climate indices.

\begin{tabular}{|c|c|c|c|c|}
\hline Station & Predictor (s) & Multiple $R$-square & Adjusted $R$-square & $p$ value \\
\hline Accra & Nino 3, Nino 3.4, Nino 4, AMM, TNA, TSA, NAO & 0.39 & 0.23 & $0.04^{*}$ \\
\hline Ada & Nino $1+2$, Nino 3.4 , Nino 4, AMM, TNA, TSA, AMO & 0.48 & 0.32 & $0.017^{*}$ \\
\hline Saltpond & Nino 3, Nino 3.4, Nino 4, AMM, NAO & 0.38 & 0.28 & $0.012^{*}$ \\
\hline Axim & Nino 4, AMM, TSA, NAO & 0.35 & 0.26 & $0.01^{*}$ \\
\hline Tema & Nino 3, Nino 3.4, Nino 4, AMM, NAO & 0.21 & 0.069 & 0.22 \\
\hline Takoradi & Nino 3, Nino 3.4, Nino 4, AMM, TNA, TSA, NAO, SOI & 0.42 & 0.24 & $0.05^{*}$ \\
\hline
\end{tabular}

Stations with significant models are identified with *.

climate indices that significantly modulate JFM SPI, explaining between 0.06 and 0.22 of JFM SPI variability. At this lag time, only Accra and Saltpond had significant model fit.

Based on the results of both correlation and AIC stepwise regression, the prominent indices linked to drought SPI variability over Coastal Ghana are AMM, AMO, NAO, TNA, TSA, Nino 1 +2, Nino 3, Nino 3.4, and Nino 4. The physical processes associated with climate indices are linked to changes in the orientation of Intertropical Convergence Zone (ITCZ) and the walker circulations. The differential heating over North and South Atlantic Ocean shifts ITCZ meridionally [16, 41] and displaces the anomalous positive rainfall toward the position of the ITCZ. AMM in its high peak enhances latent heat and evaporation over the Atlantic Ocean causing variations in trade winds circulation. AMM also enhances moisture convergence over the equatorial Atlantic leaving the Gulf of Guinea dry. When AMM is in the cold phase, the ITCZ moves from the 
TABLE 7: Summary of stepwise regression results between JFM SPI and DJF climate indices.

\begin{tabular}{|c|c|c|c|c|}
\hline Station & Predictor (s) & Multiple $R$-square & Adjusted $R$-square & $p$ value \\
\hline Accra & AMO, Nino 1 + 2, AMM & 0.26 & 0.19 & $0.024^{*}$ \\
\hline Ada & Nino $1+2$, Nino 3, Nino 4 & 0.19 & 0.11 & 0.09 \\
\hline Saltpond & Nino $1+2$, Nino 3.4 , Nino 4 & 0.23 & 0.16 & $0.04^{*}$ \\
\hline Axim & & - & - & - \\
\hline Tema & Nino $1+2$, Nino 3 , AMO, TNA, NAO & 0.31 & 0.19 & $0.05^{*}$ \\
\hline Takoradi & AMM, Nino 4 , TSA, TNA & 0.08 & -0.05 & 0.65 \\
\hline
\end{tabular}

Stations with significant models are identified with *

equatorial belt northward which favours precipitation at the Gulf of Guinea [41]. The results suggest a direct relationship between AMM and dry seasons' SPI implies that high (low) AMM leads to low (high) SPI over Coastal Ghana.

AMO, a leading mode of North Atlantic SST variability on multi-decadal timescale, is known to have played an important role in multi-decadal rainfall variability over the Sahel $[16,42]$. The warm phase of AMO is associated with the northward displacement of the ITCZ which pushes the precipitation belt northward. The warm phase of AMO weakens the northerly component of trade winds and enhances the trade winds from the south driving rain belt to the Sahel thereby depriving the Gulf of Guinea the need for precipitation. However, the cold phase of AMO displaces ITCZ southward, enhancing precipitation over Gulf of Guinea and leaving the Sahel dry [43]. The positive relationship between SPI and AMO demonstrates that AMO signals have direct remote impact on SPI over Coastal Ghana.

ENSO indices (Nino 1 + 2, Nino 3, Nino 4, and Nino 3.4) have a negative impact on dry season SPI; therefore, when ENSO is in its high phase, the seasonal SPI will be in the low phase and vice versa. During El Niño (La Niña) years, there is coupling between the ocean and the atmosphere. The ocean-atmospheric coupling during El Niño (La Niña) weakens (strengthens) the TEJ and the low-level African Easterly Jet that drives convective systems over the tropical Africa through a process called atmospheric bridge where the walker circulation would be perturbed to either suppress or enhance rainfall [44]. In an El Nino event, above normal atmospheric subsidence of the walker circulation over tropical Africa results in reduction of rainfall. The La Niña conditions enhanced rainfall in most parts of tropical Africa $[45,46]$. The inverse relationship established suggests when ENSO is in the high phase (El Niño) and low phase of ENSO (La Niña), the seasonal SPI over Coastal Ghana will be in the low phase and high phase, respectively. The study suggest the combined effect of AMM, AMO, NAO, TNA, TSA, Nino 1+2, Nino 3, Nino 3.4, and Nino 4 climate indices has great potential for predicting drought SPI over Coastal Ghana.

\section{Conclusion}

The study investigated the meteorological drought over coastal Ghana. The SPI characterizes the drought period and intensity from 1980 to 2014. The relationship between the SPI and set of climate indices was established using correlation and AIC stepwise regression methods for fitting predictive models. On an annual timescale, historical meteorological drought periods between 1983 to 1984,1988 , 1993, 1997 to 1998, 2000 to 2001, 2009, and 2012-2013 were identified. The dry seasons of JFM, NDJ, and DJF were the focal seasons of the study. The drought intensity over Coastal Ghana during these seasons can be classified as moderate to severe drought for most stations. The durations of drought over Coastal Ghana in recent times are short with weak intensities and some stations showing significant increase in the SPIs for these seasons. An indication of the wetting tendency (decrease in drought conditions) over Coastal Ghana in recent years. The temporal patterns of drought SPIs exhibited interannual variability.

The Atlantic Ocean's AMM, AMO, TSA, and TSA demonstrated positive correlation with dry seasons SPIs whereas the equatorial Pacific Nino 1+2, Nino 3, Nino 3.4, and Nino 4 showed negative association with the dry season SPIs. In general, the dominant climate indices impacting drought SPIs vary with respect to a given meteorological station. However, the prominent climate indices identified for most meteorological stations are AMM, AMO, NAO, TNA, TSA, Nino 1+2, Nino 3, Nino 3.4, and Nino 4. The model fit for the SPIs had multiple R-square ranging from 0.1 to 0.48 for some stations. The result suggests the combination of the identified climate indices can explain significant percentage variance in the dry seasons SPIs.The impact of AMM, AMO, NAO, TNA, TSA, Nino 1+2, Nino 3, Nino 3.4, and Nino 4 on dry seasons SPIs has been established and is useful for developing a robust predictive tool for drought in Coastal Ghana for disaster risk management.

\section{Data Availability}

The rainfall data used in this study were obtained from the Ghana Meteorological Agency, and climate indices were downloaded from the website of the National Oceanic and Atmospheric Administration's (NOAA) Earth Systems Research Laboratory (ESRL).

\section{Conflicts of Interest}

The authors declare that they have no conflicts of interest.

\section{Acknowledgments}

The authors gratefully acknowledge the support of their employer Ghana Space Science and Technology Institute (GSSTI) of Ghana Atomic Energy Commission (GAEC). 


\section{References}

[1] D. A. Wilhite and M. H. Glantz, "Understanding: the drought phenomenon: the role of definitions," Water International, vol. 10, no. 3, pp. 111-120, 1985.

[2] Z. Hao and V. P. Singh, "Drought characterization from a multivariate perspective: a review," Journal of Hydrology, vol. 527, pp. 668-678, 2015.

[3] G. Tsakiris, A. Loukas, D. Pangalou et al., "Drought characterization. drought management guidelines technical annex," 2007.

[4] B. Shiferaw, K. Tesfaye, M. Kassie, T. Abate, B. M. Prasanna, and A. Menkir, "Managing vulnerability to drought and enhancing livelihood resilience in sub-Saharan Africa: technological, institutional and policy options," Weather and Climate Extremes, vol. 3, pp. 67-79, 2014.

[5] A. Zargar, R. Sadiq, B. Naser, and F. I. Khan, "A review of drought indices," Environmental Reviews, vol. 19, pp. 333349, 2011.

[6] N. Zeng, "Atmospheric science: drought in the Sahel," Science, vol. 302, no. 5647, pp. 999-1000, 2003.

[7] D. Gautier, D. Denis, and B. Locatelli, "Impacts of drought and responses of rural populations in West Africa: a systematic review," Wiley Interdisciplinary Reviews: Climate Change, vol. 7, no. 5, pp. 666-681, 2016.

[8] A. Tarhule and M.-K. Woo, "Towards an interpretation of historical droughts in northern Nigeria," Climatic Change, vol. 37, no. 4, pp. 601-616, 1997.

[9] A. K. Mishra and V. P. Singh, "A review of drought concepts," Journal of Hydrology, vol. 391, no. 1-2, pp. 202-216, 2010.

[10] A. Giannini, M. Biasutti, I. M. Held, and A. H. Sobel, "A global perspective on African climate," Climatic Change, vol. 90, no. 4, pp. 359-383, 2008.

[11] P. Camberlin, S. Janicot, and I. Poccard, "Seasonality and atmospheric dynamics of the teleconnection between African rainfall and tropical sea-surface temperature: atlantic vs. ENSO," International Journal of Climatology, vol. 21, no. 8, pp. 973-1005, 2001.

[12] A. Giannini, R. Saravanan, and P. Chang, "Oceanic forcing of Sahel rainfall on interannual to interdecadal time scales," Science, vol. 302, no. 5647, pp. 1027-1030, 2003.

[13] T. Huang, L. Xu, and H. Fan, "Drought characteristics and its response to the global climate variability in the yangtze river basin, China," Water, vol. 11, no. 1, p. 13, 2019.

[14] S. Huang, Q. Huang, J. Chang, and G. Leng, "Linkages between hydrological drought, climate indices and human activities: a case study in the Columbia River basin," International Journal of Climatology, vol. 36, no. 1, pp. 280290, 2016.

[15] M. Özger, A. K. Mishra, and V. P. Singh, "Low-frequency drought variability associated with climate indices," Journal of Hydrology, vol. 364, no. 1-2, pp. 152-162, 2009.

[16] R. Zhang and T. L. Delworth, "Impact of Atlantic multidecadal oscillations on India/Sahel rainfall and Atlantic hurricanes," Geophysical Research Letters, vol. 33, no. 17, 2006.

[17] E. Ofori-Sarpong, "The 1981-1983 drought in Ghana," Singapore Journal of Tropical Geography, vol. 7, no. 2, pp. 108127, 1986.

[18] M. Baidu, L. K. Amekudzi, J. Aryee, and T. Annor, "Assessment of long-term Spatio-temporal rainfall variability over Ghana using wavelet analysis," Climate, vol. 5, no. 2, p. 30, 2017.
[19] C. Mensah, "Investigation of the onset, cessation, and length of the rainy Season over Ghana," Doctoral dissertation, University of Ghana, Accra, Ghana, 2015.

[20] H. Akaike, "A new look at the statistical model identification," IEEE Transactions on Automatic Control, vol. 19, no. 6, pp. 716-723, 1974.

[21] J. C. H. Chiang and D. J. Vimont, "Analogous pacific and atlantic meridional modes of tropical atmosphere-ocean variability," Journal of Climate, vol. 17, no. 21, pp. 4143-4158, 2004.

[22] T. B. McKee, N. J. Doesken, and J. Kleist, "The relationship of drought frequency and duration to time scales," in Proceedings of the 8th Conference on Applied Climatology, vol. 17, no. 22, pp. 179-183, American Meteorological Society, Boston, MA, USA, January 1993.

[23] D. C. Edwards, "Characteristics of 20th century drought in the United States at multiple time scales," Air Force Inst of Tech Wright-Patterson, Hobson Way, OH, USA, No. AFIT-97-051, 1997.

[24] N. B. Guttman, "Comparing the palmer drought index and the standardized precipitation Index," Journal of the American Water Resources Association, vol. 34, no. 1, pp. 113-121, 1998.

[25] S. Beguería, M. Sergio, and Vicente-Serrano, "SPEI: calculation of the standardised precipitation-evapotranspiration index," 2017, https://CRAN.R-project.org/package=SPEI.

[26] M. Svoboda, M. Hayes, and D. Wood, Standardized Precipitation Index User Guide, World Meteorological Organization, Geneva, Switzerland, 2012.

[27] M. G. Kendall, Rank Correlation Methods, Griffin, London, UK, 1975.

[28] H. B. Mann, "Nonparametric tests against trend," Econometrica, vol. 13, no. 3, pp. 245-259, 1945.

[29] P. K. Sen, "Estimates of the regression coefficient based on Kendall's tau," Journal of the American Statistical Association, vol. 63, no. 324, pp. 1379-1389, 1968.

[30] A. Araghi, M. Mousavi Baygi, J. Adamowski, J. Malard, D. Nalley, and S. M. Hasheminia, "Using wavelet transforms to estimate surface temperature trends and dominant periodicities in Iran based on gridded reanalysis data," Atmospheric Research, vol. 155, pp. 52-72, 2015.

[31] K. H. Hamed and A. R. Rao, "A modified Mann-Kendall trend test for autocorrelated data," Journal of Hydrology, vol. 204, no. 1-4, pp. 182-196, 1998.

[32] R. M. Hirsch and J. R. Slack, "A nonparametric trend test for seasonal data with serial dependence," Water Resources Research, vol. 20, no. 6, pp. 727-732, 1984.

[33] F. E. Harrell and M. F. E. Harrell, Package 'HMISC', CRAN 2018, Rockville, MD, USA, 2019.

[34] F. Mekanik, M. A. Imteaz, S. Gato-Trinidad, and A. Elmahdi, "Multiple regression and artificial neural network for longterm rainfall forecasting using large scale climate modes," Journal of Hydrology, vol. 503, pp. 11-21, 2013.

[35] T. Gao and L. Xie, "Multivariate regression analysis and statistical modeling for summer extreme precipitation over the Yangtze River basin," Advances in Meteorology, China, 2014.

[36] W. N. Venables and B. D. Ripley, Modern Applied Statistics with S, Springer, New York, NY, USA, 4th edition, 2002.

[37] R. Kasei, B. Diekkrüger, and C. Leemhuis, "Drought frequency in the Volta basin of West Africa," Sustainability Science, vol. 5, no. 1, p. 89, 2010.

[38] I. Masih, S. Maskey, F. E. F. Mussá, and P. Trambauer, “A review of droughts on the African continent: a geospatial and 
long-term perspective," Hydrology and Earth System Sciences, vol. 18, no. 9, p. 3635, 2014.

[39] S. E. Nicholson, "The West African Sahel: a review of recent studies on the rainfall regime and its interannual variability," ISRN Meteorology, vol. 2013, Article ID 453521, 2013.

[40] G. M. L. Quenum, N. A. Klutse, D. Dieng et al., "Identification of potential drought areas in West Africa under climate change and variability," Earth Systems and Environment, vol. 3, pp. 429-444, 2019.

[41] S.-P. Xie and J. A. Carton, "Tropical atlantic variability: patterns, mechanisms, and impacts," Earth's Climate, vol. 170, pp. 121-142, 2004.

[42] J. R. Knight, C. K. Folland, and A. A. Scaife, "Climate impacts of the Atlantic multidecadal oscillation," Geophysical Research Letters, vol. 33, no. 17, 2006.

[43] E. R. Martin and C. D. Thorncroft, "The impact of the AMO on the West African monsoon annual cycle," Quarterly Journal of the Royal Meteorological Society, vol. 140, no. 678, pp. 31-46, 2014.

[44] B. Preethi, T. P. Sabin, J. A. Adedoyin, and K. Ashok, "Impacts of the ENSO modoki and other tropical indo-pacific climatedrivers on African rainfall," Scientific Reports, vol. 5, 2015.

[45] S. E. Nicholson and J. C. Selato, "The influence of La Nina on African rainfall," International Journal of Climatology, vol. 20, no. 14, pp. 1761-1776, 2000.

[46] S. E. Nicholson and J. Kim, "The relationship of the El niñosouthern oscillation to African rainfall," International Journal of Climatology, vol. 17, no. 2, pp. 117-135, 1997. 